\title{
Review \\ Contemporary Pillars of Heart Failure with Reduced Ejection Fraction Medical Therapy
}

\author{
Eldad Rahamim ${ }^{1, *,+} \oplus$, Dean Nachman ${ }^{1,+}{ }^{+}$, Oren Yagel ${ }^{1}$, Merav Yarkoni ${ }^{1}$, Gabby Elbaz-Greener ${ }^{1} \oplus$, Offer Amir ${ }^{1,2}$ \\ and Rabea Asleh 1,*(i) \\ 1 Heart Institute, Hadassah Medical Center, Faculty of Medicine, Hebrew University of Jerusalem, \\ Jerusalem 91120, Israel; Dean@hadassah.org.il (D.N.); oreny@hadassah.org.il (O.Y.); \\ myarkoni@hadassah.org.il (M.Y.); gabbyelbaz@yahoo.com (G.E.-G.); Oamir@hadassah.org.il (O.A.) \\ 2 Azrieli Faculty of Medicine, Bar-Ilan University, Safed 1311502, Israel \\ * Correspondence: eldad.rahamim@gmail.com (E.R.); Rasleh@hadassah.org.il (R.A.); \\ Tel.: +972-52-9593892 (E.R.); +972-2-6775266 (R.A.) \\ + These authors contributed equally to this work.
}

Citation: Rahamim, E.; Nachman, D.; Yagel, O.; Yarkoni, M.; Elbaz-Greener, G.; Amir, O.; Asleh, R. Contemporary Pillars of Heart Failure with Reduced Ejection Fraction Medical Therapy. J. Clin. Med. 2021, 10, 4409. https:// doi.org/10.3390/jcm10194409

Academic Editors: Jacob George and Sorel Goland

Received: 7 September 2021

Accepted: 22 September 2021

Published: 26 September 2021

Publisher's Note: MDPI stays neutral with regard to jurisdictional claims in published maps and institutional affiliations.

Copyright: (c) 2021 by the authors. Licensee MDPI, Basel, Switzerland. This article is an open access article distributed under the terms and conditions of the Creative Commons Attribution (CC BY) license (https:// creativecommons.org/licenses/by/ $4.0 /)$.

\begin{abstract}
Heart failure with reduced ejection fraction (HFrEF) is a clinical condition associated with cardiac contractility impairment. HFrEF is a significant public health issue with a high morbidity and mortality burden. Pathological left ventricular (LV) remodeling and progressive dilatation are hallmarks of HFrEF pathogenesis, ultimately leading to adverse clinical outcomes. Therefore, cardiac remodeling attenuation has become a treatment goal and a standard of care over the last three decades. Guideline-directed medical therapy mainly targeting the sympathetic nervous system and the renin-angiotensin-aldosterone system (RAAS) has led to improved survival and a reduction in HF hospitalization in this population. More recently, novel pharmacological therapies targeting other pathways implicated in the pathophysiology of HFrEF have emerged at an exciting rate, with landmark clinical trials demonstrating additive clinical benefits in patients with HFrEF. Among these novel therapies, angiotensin receptor-neprilysin inhibitors (ARNI), sodium-glucose cotransporter-2 inhibitors (SGLT2i), vericiguat (a novel oral guanylate cyclase stimulator), and omecamtiv mecarbil (a selective cardiac myosin activator) have shown improved clinical benefit when added to the traditional standard-of-care medical therapy in HFrEF. These new comprehensive data have led to a remarkable change in the medical therapy paradigm in the setting of HFrEF. This article will review the pivotal studies involving these novel agents and present a suggestive paradigm of pharmacological therapy representing the 2021 European Society of Cardiology (ESC) guidelines for the treatment of chronic HFrEF.
\end{abstract}

Keywords: heart failure with reduced ejection fraction; novel medical therapy; hospitalization; mortality; morbidity

\section{Introduction}

Heart failure (HF) is a significant public health problem affecting millions of individuals globally with high morbidity and mortality rates [1,2]. In people older than 60 years, $\mathrm{HF}$ is the leading cardiovascular (CV) reason for hospitalization [3]. HF carries a substantial financial burden in developed countries, with its prevalence continuing to rise over time [4-6]. HF has an estimated prevalence of over 37.7 million patients worldwide. In the United States, the estimated prevalence of HF is more than 6 million patients over the age of 20, with over half a million patients newly diagnosed with HF every year [7-10].

Heart failure is a chronic condition of cardiac functional impairment with various etiologies, pathophysiologies, and clinical presentations. Patients with HF experience a variety of symptoms with a significant impact on their quality of life. Common symptoms include shortness of breath, poor exercise tolerance, and fatigue, which adversely affect daily function $[10,11]$. HF is differentiated into three major categories based on the left 
ventricular (LV) ejection fraction (EF). According to the recently released 2021 European Society of Cardiology (ESC) HF guidelines, HF with reduced EF (HFrEF) is defined as HF with $\mathrm{EF} \leq 40 \%$. HF with EF between $41 \%$ and $49 \%$ (previously defined as HF with mid-range HF) is now termed HF with mildly reduced EF (HFmrEF), whereas HF with preserved $\mathrm{EF}$ (HFpEF) is defined as $\mathrm{HF}$ with $\mathrm{EF} \geq 50 \%$ (similar to the previous $2016 \mathrm{ESC}$ guidelines) [12-14].

HFrEF is often accompanied by pathological LV remodeling and dilatation, which leads to adverse outcomes. Reversing cardiac remodeling became a treatment goal and standard of care more than 20 years ago [15]. These patients are recurrently hospitalized, and not rarely, HF patients may require advanced therapies. Guideline-directed medical therapy has led to an increase in survival rates in these patients, with the main target of treatment being the sympathetic nervous system and the renin-angiotensin-aldosterone system (RAAS) [16]. Low effective stroke volume, as seen in HFrEF, typically leads to sympathetic nervous system and RAAS activation. The activation of these systems results in vasoconstriction and fluid retention, thereby contributing to adverse remodeling in HF.

\section{Traditional Pillar-Directed Medical Therapy}

Sympathetic activation has harmful effects on morbidity and mortality in HF [17]. The beta-adrenergic blocker bisoprolol was found to reduce HF hospitalizations and mortality in the Cardiac Insufficiency Bisoprolol Study (CIBIS) [18]. These benefits have only been found in specific beta-blockers, including metoprolol, carvedilol, and bisoprolol, but not as a class effect. The CIBIS-II trial comparing bisoprolol versus placebo in stable HFrEF patients with New York Heart Association (NYHA) III-IV has demonstrated a 5\% absolute risk reduction in all-cause mortality [19]. Similarly, results obtained from HFrEF patients treated with metoprolol versus placebo have shown a $34 \%$ relative risk reduction in allcause mortality per patient-year in the Metoprolol CR/XL Randomized Intervention Trial in Congestive Heart Failure (MERIT-HF), leading to early discontinuation of the trial due to ethical reasons [20]. In 2002, carvedilol was also found to reduce annual mortality rates, HF hospitalizations, and cardiogenic shock compared to placebo in HFrEF patients in the Carvedilol Prospective Randomized Cumulative Survival (COPERNICUS) trial [21]. Head-to-head trials among the three beta-blockers have shown similar benefits without evidence of a preferred agent over the other [22].

Angiotensin-converting enzyme (ACE) inhibitors inhibit the conversion of angiotensin I to angiotensin II. The CONSENSUS trial has shown an $18 \%$ absolute risk reduction in mortality with enalapril compared with placebo among HFrEF patients with NYHA class IV symptoms after six months of follow-up [23]. Subsequent studies have shown consistent results in patients with NYHA class II and III symptoms [24]. A trend towards increased survival has also been noticed with isosorbide dinitrate and hydralazine. However, in two trials, the V-HeFT and the V-HeFT II, treatment with enalapril has reduced mortality by $7 \%$ compared to isosorbide dinitrate and hydralazine $[25,26]$. The SAVE trial has also shown a $19 \%$ decreased mortality with captopril compared with placebo as well as a significant reduction in ventricular dysfunction secondary to ischemia [27]. Based on these studies, ACE inhibitors are considered a class I recommendation in patients with HFrEF [16].

Angiotensin receptor blockers (ARBs) inhibit the downstream effects of angiotensin II by blocking its binding to angiotensin I receptors. The Val-HeFT trial has shown that the combination of ACE inhibitors and ARB treatments could cause acute renal failure, and though it resulted in morbidity reduction, no mortality benefit was observed [28]. In 2003, the Candesartan in Heart Failure-Assessment of Reduction in Mortality and Morbidity (CHARM) trial demonstrated a significant reduction in the composite outcome of HF hospitalization or CV mortality in NYHA class II to IV HFrEF patients treated with candesartan as compared to those treated with placebo [29,30]. Accordingly, ARBs are considered as a class I recommendation in symptomatic HFrEF patients [16].

Mineralocorticoid receptor antagonists (MRAs) inhibit the aldosterone receptor, thus hindering sodium and water retention. The Randomized Aldactone Evaluation Study 
(RALES) has demonstrated an 11\% absolute risk reduction in all-cause mortality and a $35 \%$ relative risk reduction in HF hospitalization in HFrEF patients when treated with spironolactone versus placebo. This trial has also shown an improved functional capacity in patients with an LVEF < 35\% and NYHA class III and IV [31]. Similarly, a 15\% relative risk reduction in mortality was found with eplerenone in the Eplerenone Post-Acute Myocardial Infarction Heart Failure Efficacy and Survival Study (EPHESUS) [32]. The Eplerenone in Mild Patients Hospitalization and Survival Study in Heart Failure (EMPHASIS-HF) has shown consistent results, which further emphasized the importance of MRAs in the setting of $\mathrm{HFrEF}$, which is considered as a class I recommendation for patients with $\mathrm{EF}<35 \%$ and NYHA class II to IV symptoms [33].

The combination of isosorbide dinitrate and hydralazine has shown a trend towards improved survival in the Vasodilator Heart Failure Trial (V-HeFT) compared with prazosin or placebo in HFrEF patients [34]. The recommendation of combining ACE inhibitors with isosorbide dinitrate and hydralazine is based on the African American Heart Failure Trial (A-HeFT), demonstrating a $4 \%$ improved survival and a $33 \%$ reduction in first $\mathrm{HF}$ hospitalization in HFrEF patients [35].

The SHIFT trial (Systolic Heart failure treatment with the If inhibitor ivabradine) involving NYHA II-IV HFrEF patients with a resting heart rate $\geq 70$ and at least one HF hospitalization in the previous year demonstrated an $18 \%$ relative risk reduction in the composite outcome of HF mortality or hospitalization for HF [36]. The addition of ivabradine is considered a class IIa recommendation by the European Society of Cardiology (ESC) to reduce HF hospitalization in symptomatic patients with NYHA II-III HFrEF [37].

Other pharmacologic treatments, such as digoxin and diuretics, have not been proven to improve survival, although a decrease in HF hospitalization has been observed with digoxin use [38]. Diuretic therapy is currently indicated in patients with volume overload to maintain a volume balance and reduce the risk of rehospitalization. Digoxin can be added to reduce the risk of HF hospitalization in patients who remain symptomatic despite treatments with class I recommendation medical therapies for HFrEF.

Although HF drugs significantly impact the field, a quarter of patients will still suffer severe symptoms, hospitalizations, and mortality despite optimal treatment. Consequently, novel pharmacological approaches to HF management are vital $[7,39,40]$. The purpose of this article is to review some of the most recent advancements in pharmacological therapies for heart failure with reduced ejection fraction and future perspectives.

\section{Novel Pillar-Directed Medical Therapy}

A quarter of HF patients will still suffer severe symptoms, hospitalizations, and mortality despite optimal treatment. Consequently, novel pharmacological approaches to HF management are pivotal $[9,39,40]$. Novel pharmacologic therapies targeting unique pathways involved in the pathogenesis of HFrEF have increasingly become a part of the standard-of-care medical therapy in the past few years. Neprilysin is an endopeptidase responsible for the degradation of natriuretic and other vasoactive peptides under normal conditions. Neprilysin inhibition increases natriuretic peptide levels and other vasodilatory substances and leads to natriuretic and vasodilatory effects. The administration of synthetic natriuretic peptides has not improved outcomes in acute HF [41]. Early trials failed to prove improved outcomes with neprilysin inhibition alone or when combined with ACE inhibitors $[42,43]$. The combination of neprilysin with ACE inhibitors showed an increased incidence of angioedema, leading to early termination of the trial [44]. The formerly known LCZ696 molecule of sacubitril/valsartan (ARNi) had a unique design of blocking both the renin-angiotensin system and neprilysin activity [45-47]. The Prospective Comparison of ARNi with ACE inhibitor to Determine Impact on Global Mortality and Morbidity in Heart Failure (PARADIGM-HF) trial, involving NYHA class II-IV HFrEF patients, was terminated early due to a $20 \%$ relative risk reduction in the composite outcome of CV mortality or HF hospitalization, and a $16 \%$ relative risk reduction in all-cause mortality with ARNi compared with enalapril in addition to standard therapies in HFrEF [48]. The 
Comparison of Sacubitril-Valsartan versus Enalapril on Effect on N-terminal (NT) pro B-type-natriuretic peptide (BNP) (NT-proBNP) in Patients Stabilized from an Acute Heart Failure Episode (PIONEER-HF) trial has shown that this treatment is safe and more effective in reducing NT-proBNP levels than ACE inhibitors among patients hospitalized for acute decompensated HF, including ACE inhibitor/ARB-naïve patients [49].

Patients with HFrEF receiving ACE inhibitors or ARBs should be transferred to ARNi when possible, given the greater clinical benefit with ARNi use. ACE inhibitors should be held for $36 \mathrm{~h}$ before starting $\mathrm{ARNi}$, while there is no need for this interruption in treatment with ARBs. The initial dosage of ARNi depends on the preceding ACEi/ARB dose, but it is strongly recommended to achieve a maximal dose of $200 \mathrm{mg}$ (sacubitril/valsartan $97 / 103 \mathrm{mg}$ ) twice daily. A lower dose (sacubitril/valsartan $24 / 26 \mathrm{mg}$ twice daily) should be considered in patients at the age of 75 years or older, with low blood pressure (systolic pressure of 100 to $110 \mathrm{mmHg}$ ), estimated GFR $<60 \mathrm{~mL} / \mathrm{min} / 1.73 \mathrm{~m}^{2}$, or those with significant liver disease. Dosage can be doubled every $2-4$ weeks up to the maximally tolerated dose. In an analysis of high-risk patients in the PIONEER-HF study, the reduction in cardiovascular death or rehospitalization after hospitalization for acute decompensated heart failure was similar to the significant risk reduction in the original trial. Compared to enalapril, the initiation of sacubitril/valsartan does not increase adverse events including symptomatic hypotension, worsening renal function, and hyperkalemia [50].

\subsection{Sodium-Glucose Cotransporter-2 Inhibitors (SGLT2i)}

Sodium-glucose cotransporter-2 inhibitors (SGLT2i) target the sodium-glucose cotransporter-2 expressed in the early proximal tubules in the kidney, which is responsible for most renal glucose filtration (Figure 1). These medications were initially used as antihyperglycemic agents in patients with type 2 diabetes [51,52]. The mechanisms of the benefits of SGLT2 inhibition are still being elucidated and are likely multifactorial. Besides glycemic control, SGLT2i have additional favorable effects on blood pressure, weight, uric acid concentrations, albuminuria, lipid profile, and hematocrit, as well as direct cardiac effects, including CV and HF benefits [51,53-56].

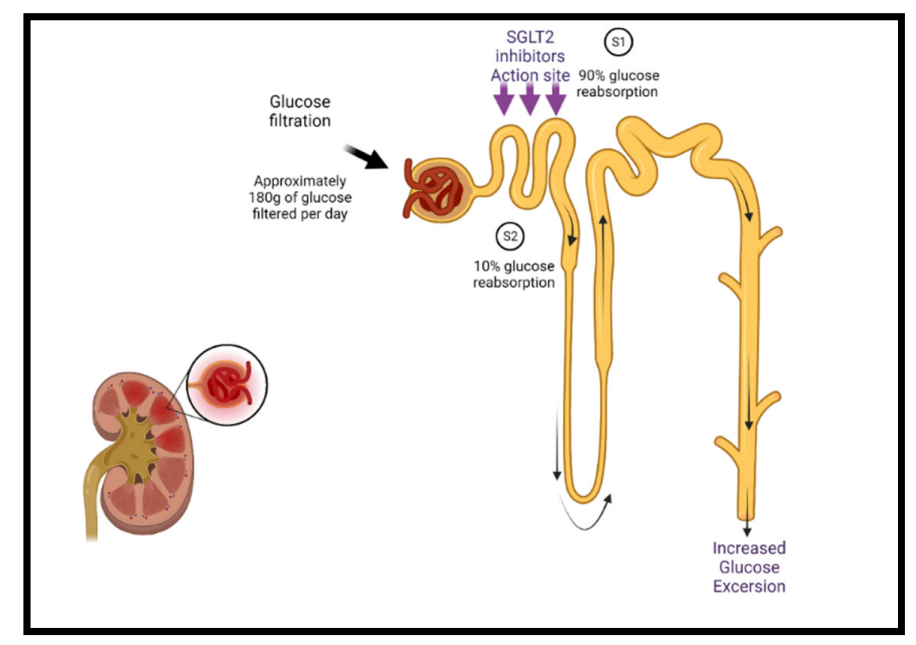

Figure 1. The mechanism of SGLT2 class inhibitors. Under normal conditions, glucose filtration at the nephron reabsorbs glucose back into the bloodstream, approximating 180 g per day. Sodiumglucose cotransporters are present in the proximal convoluted tubule of the nephron (S1 segment) containing SGLT2 and at the distal end (S2 segment) containing SGLT1. SGLT2 is responsible for the reabsorption of $90 \%$ of the sodium/glucose, whereas SGLT1 is responsible for the remaining $10 \%$. SGLT2 inhibitors act on SGLT2 proteins at the S1 position and reduce sodium/glucose reabsorption, leading to increased urinary excretion of sodium and glucose, finally lowering blood glucose levels. Additional cardiac-specific mechanisms have been proposed and are currently being studied. SGLT2 = sodium-glucose cotransporter- 2 . 
Few mechanisms have been proposed to explain the improvement in HF outcomes by SGLT2i. SGLT2i cause osmotic diuresis and natriuresis, which may reduce cardiac preload. Additional suggested mechanisms include direct vasodilation and blood pressure decrease, anti-inflammatory properties, and hematocrit increase [57-59].

Among patients with type 2 diabetes mellitus (DM), the EMPA-REG trial evaluating empagliflozin in patients with established CVD showed a reduction in HF hospitalization and CV death. Over $10 \%$ of the patients participating in this trial had an underlying HF diagnosis, for whom a consistent and significant reduction in HF hospitalization has been observed in the intervention group [60]. The DECLARE TIMI 58 trial [61], involving patients with and without established CVD, showed a lower rate of CV death or hospitalization from HF but not a significant reduction in major CV adverse events (MACE). The CANVAS trial evaluating canagliflozin in patients with type 2 DM and high cardiovascular risk or established CVD (14\% with underlying HF) found a lower risk of $\mathrm{MACE}$, hospitalization for $\mathrm{HF}$, and renal protection, but without a significant reduction in mortality $[60,62,63]$.

Given the consistent results showing a remarkable decrease in HF hospitalization in patients with DM and high CV disease risk, the safety and efficacy of SGLT2i in HFrEF patients regardless of having DM were evaluated in the DAPA-HF and EMPEROR-reduced trials. In the DAPA-HF trial [64], dapagliflozin reduced CV mortality by $18 \%$ and heart failure hospitalization by $30 \%$, as well as causing a significant reduction in all-cause mortality. In the EMPEROR-reduced trial [65], empagliflozin moderated the risk of the primary composite outcome (CV death and HF hospitalization) by $25 \%$, mostly by a lower risk of HF hospitalization, with no significant decrease in CV death $[64,65]$.

A meta-analysis combining the DAPA-HF and EMPEROR-reduced trials found a 13\% reduction in all-cause mortality, a 14\% reduction in CV death regardless of background therapy, and a 31\% reduction in the risk of the first hospitalization for HF [66].

Sotagliflozin is a novel oral anti-diabetic drug with a unique dual-receptor binding affinity for SGLT1 and SGLT2 [67]. The randomized controlled trial (RCT) SOLOIST-WHF evaluated the early use of sotagliflozin in diabetic patients with HFrEF, either before or within three days of discharge after an episode of decompensated HF. The study has demonstrated a significant reduction in the primary combined endpoint of CV death, hospitalization for HF, or urgent visits for HF management. Ertugliflozin is another new SGLT2 inhibitor, which was evaluated for CV outcomes in diabetic patients in the VERTISCV trial [68]. Ertugliflozin was non-inferior to placebo for major adverse CV events and reduced hospitalization for HF by $30 \%$. The use of empagliflozin in patients with HF with preserved ejection fraction in the EMPEROR-PRESERVED trial reduced the combined risk of cardiovascular death or hospitalization for heart failure. This benefit was present in patients with and without diabetes. In this trial, a third of patients had EF between $40 \%$ and 50\%. This benefit is a promising avenue of treatment for patients with HFmrEF [69]. Dapagliflozin is another SGLT2 inhibitor under investigation for patients with HFpEF in the ongoing DELIVER trial.

In the 2021 European Society of Cardiology (ESC) heart failure guidelines, medications that were solely recommended for patients with reduced ejection fraction have shown benefit in HFmrEF and are now indicated as a class IIB recommendation in this cohort. These include ACE inhibitors, ARBs, beta-blockers, MRAs, SGLT2, and sacubitril/valsartan (ARNi). Diuretics are recommended in these patients with congestion to relieve symptoms [14].

\subsection{Vericiguat}

The nitric oxide (NO)-cyclic guanosine monophosphate (cGMP) pathway plays a key role in the regulation of the CV system [70,71]. NO mainly regulates cardiac function by activating soluble guanylate cyclase (sGC), which catalyzes the formation of cGMP, resulting in protein kinase G (PKG) activation [70,72]. PKG modulates cardiac and vascular muscle contraction and energy consumption by decreasing intracellular calcium concentration and 
myosin light chain activity [73]. The phosphodiesterase (PDE) enzyme family members hydrolyze cGMP, negatively regulating the signaling pathway [74]. The downregulation of the pathway exerts deleterious CV effects, including vascular dysfunction, hypertension, fibrosis, adverse cardiac remodeling, and ultimately the development of HFrEF or HFpEF [70,75-77].

Clinical trials of NO donors and PDE inhibitors in HF patients showed no clinical benefit [78-82]. A novel class of medications directly targeting different components of the cGMP pathway, such as sGC agonists, has recently been studied as a therapeutic option for HFrEF. First, sGC activators (e.g., cinaciguat and ataciguat) activate sGC in its oxidized Haem-free form independently of endogenous $\mathrm{NO}[83,84]$. Cinaciguat demonstrated profound hypotension with no clinical, cardiac biomarkers or cardiac index improvement when administered to acute decompensated HF patients in clinical trials, and consequently, its development for HF management was halted $[85,86]$. It has been speculated that sGC activation irrespective of endogenous NO might be responsible for the substantial debilitating vasodilatory effect of cinaciguat [82].

In contrast to sGC activators, sGC stimulators (e.g., vericiguat and riociguat) potentiate endogenous NO by binding directly to sGC (Figure 2) [84]. In the SOCRATES-Reduced dose defining phase $2 \mathrm{~b}$ clinical trial, vericiguat was evaluated in 456 participants with worsening HFrEF. At 12 weeks of follow-up, the primary endpoint of decreased NT-proBNP levels was not met, yet a prespecified secondary analysis demonstrated a dose-response relationship. Furthermore, an improvement in the rate of $\mathrm{CV}$ death and HF hospitalization as well as a significant improvement in LVEF was noticed in a dose-response manner [87]. The VICTORIA study, a phase 3 RCT, has examined the efficacy and safety of vericiguat in 5050 patients with $\mathrm{HF}$ and $\mathrm{EF}<45 \%$, elevated NT-proBNP, and recent clinical worsening. Over 10.8 months of follow-up, the primary composite endpoint of CV death or first HF hospitalization was significantly lower in the vericiguat versus the placebo arms ( $35.5 \%$ vs. $38.5 \%, p=0.02$ ). The difference was mainly driven by a reduction in HF hospitalization, while the difference in the $\mathrm{CV}$ death was not significantly different between the two groups. Symptomatic hypotension and syncope rates did not differ between the treatment and control groups (9.1\% vs. $7.9 \%, p=0.12$; and $4 \%$ vs. $3.5 \%, p=0.3$, respectively) [88]. Following the results of the VICTORIA study, vericiguat received regulatory approval by the FDA for patients with symptomatic chronic HFrEF.

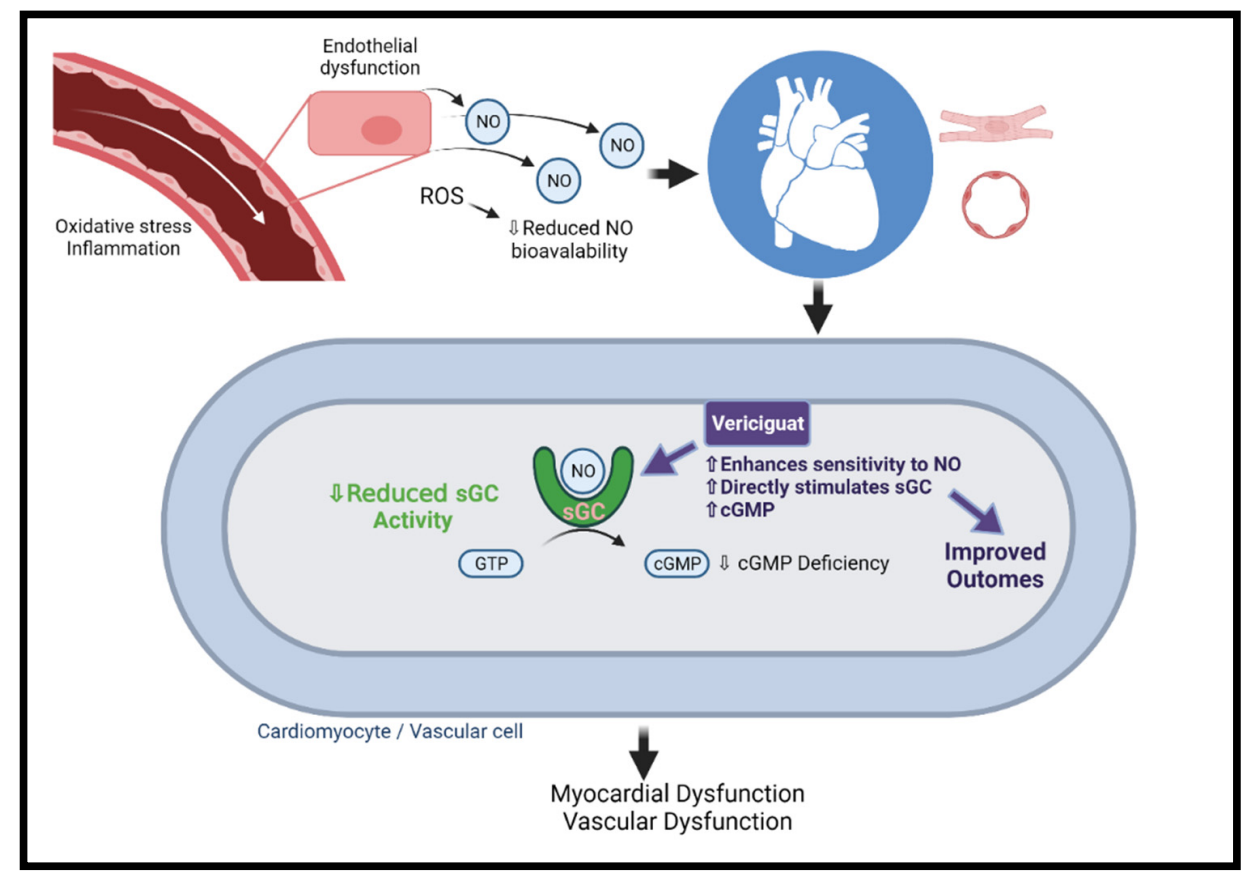

Figure 2. The mechanism of vericiguat. Under normal conditions, NO is generated in endothelial cells and diffuses to neighboring tissues. NO enters vascular/cardiac muscle cells in the heart and 
stimulates the intracellular receptor sGC to generate CGMP. In HF, there is endothelial dysfunction due to oxidative stress and inflammation and ROS, and ROS reduce NO bioavailability, leading to insufficient activation of sGC. The resulting cGMP deficiency is associated with microvascular dysfunction, cardiomyocyte stiffness, and fibrosis, ultimately leading to myocardial dysfunction. Vericiguat can sensitize sGC and directly stimulate the enzyme to the limited amounts of endogenous NO. $c G M P=$ cyclic guanosine monophosphate; $\mathrm{NO}=$ nitric oxide; $\mathrm{ROS}=$ reactive oxygen species; sGC = soluble guanylate cyclase. Created with BioRender.com.

\subsection{Omecamtiv Mecarbil}

Myocardial contraction is a result of chemical energy transformation into mechanical energy. Actin, myosin, and other regulatory proteins generate the force needed for contraction. It also involves ATP hydrolysis and myosin-actin cross bridging, which both play a key role in cardiac contractility [89]. Inotropic drugs increase myocardial contractility through the increase in intracellular cAMP and calcium through different mechanisms. However, the use of inotropes is associated with increased myocardial oxygen consumption and tachyarrhythmia, which may increase mortality as shown in previous studies [89-91].

Omecamtiv mecarbil, formerly known as CK-1827452, was the first agent developed to accelerate the transition of the actin-myosin complex from weakly bound to a firmly bound configuration (Figure 3) [90-92]. Omecamtiv mecarbil was found to improve cardiac function in patients with HFrEF. However, higher infused doses have led to cardiac ischemia in some cases $[92,93]$. Safety and tolerability were tested and found not to be different from placebo, including time to angina, exercise duration, or ischemic ECG changes [94].

In the ATOMIC-AHF study, patients with reduced ejection fraction admitted with acute decompensated HF were randomized to receive intravenous omecamtiv mecarbil vs. placebo for $48 \mathrm{~h}$. There was no significant effect on dyspnea relief at 6,24 , and $48 \mathrm{~h}$ compared with the pooled cohort. There was a benefit on dyspnea relief at $48 \mathrm{~h}$ in a supplemental prespecified analysis compared with the paired placebo. There was no effect on 30-day mortality or worsening HF, length of hospitalization, or NT-proBNP levels [95].

The COMIC-HF trial studied the pharmacokinetics of modified oral dosing along with safety, tolerability, and echocardiographic and biomarker changes over 20 weeks. This trial showed increased systolic ejection time and stroke volume, reduced heart rate and left ventricular end-systolic volume (LVESV), reduced left ventricular end-diastolic volume (LVEDV), and lower NT-proBNP [96]. The largest phase III trial by Teerlink et al. has shown that HFrEF patients who received omecamtiv mecarbil had a lower incidence of HF events or death from CV causes than patients receiving placebo. CV mortality and all-cause mortality did not differ significantly between the two groups and there was no difference in the Kansas City Cardiomyopathy Questionnaire total symptom score. After 24 weeks, NT-proBNP was 10\% lower in the omecamtiv mecarbil group. There was no difference in the frequency of ischemic ventricular arrhythmia events between the groups [97]. A subgroup analysis of the GALACTIC-HF trial by $X$ et al. has shown a more remarkable clinical benefit among HFrEF patients with more pronounced LV systolic dysfunction (represented by lower EF) than those with less severe LV systolic dysfunction [98]. In these trials, there was no increase in angina or ACS events due to omecamtiv mecarbil's lack of energy demand increase. There was a mild increase in troponin levels of $4 \mathrm{ng} / \mathrm{L}$ [97].

These findings create a new avenue of treatments for patients with factors limiting pharmacological therapies, such as low blood pressure and low glomerular filtration rate. This drug can be prescribed to patients with systolic blood pressure as low as $85 \mathrm{mmHg}$ and an estimated glomerular filtration rate of $25 \mathrm{~mL} / \mathrm{min}$, creating a new treatment alternative. 


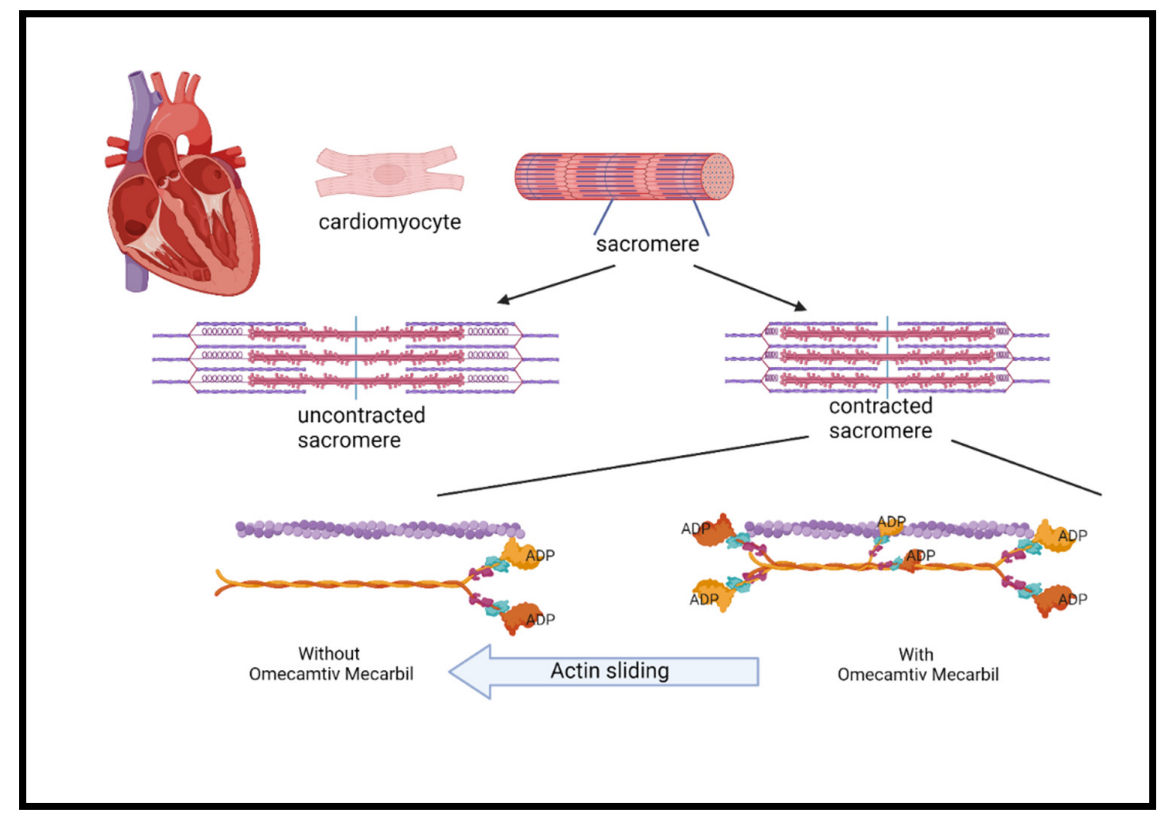

Figure 3. The mechanism of omecamtiv mecarbil. The cardiac myocyte is composed of repeated myofibril units that contain myofilaments. Each unit, termed a sarcomere, is composed of thick and thin filaments, myosin (pink/orange), and actin (purple), respectively. Myosin contains two heads that serve the site of ATPase enzyme that hydrolyzes ATP required for the actin and myosin cross-bridge formation. These heads interact with a binding site on actin and cause the sarcomere length to shorten during contraction. Phosphate is released from ADP to create the force. The more myosin heads containing ADP, the greater the force in each heart contraction. OM binds with highest affinity to myosin heads containing ADP and stabilizes the myosin head in this confirmation 6-fold compared to the other confirmation states. A greater force is produced during each cycle of cardiac contraction. The mechanism has the analogy of hands holding on a rope in which the more hands, the greater the force. ADP = adenosine diphosphate; ATP = adenosine triphosphate; $\mathrm{OM}=$ omecamtiv mecarbil.

The management of HF patients includes four major pillars of pharmacological treatment. The ideal patient will be managed with ARNi, beta-blockers, MRAs, and an SGLT2 inhibitor (Table 1). Beta-blockers and MRAs are longstanding class I recommendations for the treatment of HFrEF. ARNi became a class I recommendation in the 2016 ESC guidelines for the treatment of chronic heart failure for patients with reduced EF [99]. In the 2021 European Society of Cardiology (ESC) HF guidelines, SGLT2 inhibitors became the fourth crucial pillar of treatment for patients with reduced EF (and HFpEF) with or without diabetes mellitus. An emerging new approach will be tailored treatment for HFrEF patients based on their phenotype (Figure 4) [14]. The tailored treatment approach is applied as a general approach. Clinicians can put more emphasis on one of the pillars depending on the clinical scenario. Patients with marked hypertension might benefit from emphasis on treatment with ARNi. Patients with chronic kidney disease (CKD) with hyperkalemia and hypotension might benefit from emphasizing the SGLT2 inhibitors pillar. 
Table 1. Summary of major HFrEF treatment clinical trials.

\begin{tabular}{|c|c|c|c|c|c|c|c|}
\hline Year & Reference & Patient Characteristics & Treatment & Mean Follow Up & Primary Endpoint & Secondary Endpoint & Comments \\
\hline \multicolumn{8}{|c|}{ Beta blockers } \\
\hline 1994 & CIBIS [18] & $\begin{array}{c}641 \text { patients with chronic } \\
\text { HF NYHA III-IV, } \\
\text { LVEF }<40 \%\end{array}$ & $\begin{array}{l}1.25-5 \mathrm{mg} \text { of } \\
\text { bisoprolol vs. } \\
\text { placebo }\end{array}$ & 1.9 years & $\begin{array}{l}\text { Mortality with } \\
\text { bisoprolol vs. placebo HR } 0.80 \\
\text { (95\% CI: } 0.56-1.15, p=0.22)\end{array}$ & $\begin{array}{l}\text { NS in SCD rate, NS } \\
\text { mortality rate related to } \\
\text { VT/VF, improved } \\
\text { functional status of } \\
\text { patients on bisoprolol }\end{array}$ & \\
\hline 1999 & CIBIS-II [19] & $\begin{array}{l}2647 \text { NYHA III-IV patients, } \\
\text { LVEF } \leq 35 \% \text {, } \\
\text { receiving standard therapy } \\
\text { with diuretics and ACEi }\end{array}$ & $\begin{array}{l}\text { Bisoprolol } \\
1.25-10 \mathrm{mg} \text { vs. } \\
\text { placebo }\end{array}$ & 1.3 years & $\begin{array}{c}\text { All-cause mortality } \\
\text { with bisoprolol vs. } \\
\text { placebo HR } 0.66(95 \% \text { CI: } \\
0.54-0.81, p<0.0001)\end{array}$ & $\begin{array}{l}\text { Bisoprolol improved } \\
\text { sudden deaths HR } 0.56 \\
95 \% \text { (CI: 0.39-0.80, } \\
p=0.0011)\end{array}$ & $\begin{array}{c}\text { Terminated early, } \\
\text { after the second } \\
\text { interim analysis, } \\
\text { because of a } \\
\text { significant mortality } \\
\text { benefit }\end{array}$ \\
\hline 1999 & MERIT-HF [20] & $\begin{array}{l}3991 \text { patients with chronic } \\
\text { HF in NYHA functional } \\
\text { class II-IV and with } \\
\text { LVEF } \leq 40 \% \text {, stabilized } \\
\text { with optimal standard } \\
\text { therapy }\end{array}$ & $\begin{array}{c}\text { Metoprolol CR/XL } \\
12.5 \mathrm{mg} \text { (NYHA } \\
\text { III-IV) or } 25.0 \mathrm{mg} \\
\text { once daily (NYHA II), } \\
\text { target dose } 200 \mathrm{mg} \\
\text { up-titrated over } \\
8 \text { weeks vs. placebo }\end{array}$ & 1 year & $\begin{array}{c}\text { All-cause mortality } \\
\text { with metoprolol CR/XL vs. } \\
\text { placebo HR } 0.66(95 \% \mathrm{CI} \\
0.53-0.81, p=0.00009 \text { or } \\
\text { adjusted for interim analyses } \\
\qquad p=0.0062)\end{array}$ & $\begin{array}{c}\text { Metoprolol CR/XL } \\
\text { improved sudden deaths } \\
\text { HR } 0.59 \text { (CI: } 0.45-0.78 \\
p=0.0002) \text { and deaths } \\
\text { from worsening HF HR } \\
0.51 \text { (CI: } 0.33-0.79 \\
p=0.0023)\end{array}$ & $\begin{array}{c}\text { Terminated early } \\
\text { because of a } \\
\text { significant mortality } \\
\text { benefit }\end{array}$ \\
\hline 2002 & $\begin{array}{c}\text { COPERNICUS } \\
{[21]}\end{array}$ & $\begin{array}{c}2289 \text { patients with HF } \\
\text { symptoms at rest or on } \\
\text { minimal exertion and with } \\
\text { LVEF }<25 \%\end{array}$ & $\begin{array}{c}\text { Carvedilol } 3.125 \mathrm{mg} \\
\text { twice daily } \\
\text { up-titrated to } 25 \mathrm{mg} \\
\text { twice daily vs. } \\
\text { placebo }\end{array}$ & 10.4 months & $\begin{array}{c}\text { Combined risk of mortality or } \\
\text { CV hospitalization HR } 0.73 \\
\text { (95\% CI: } 0.63-0.86, p=0.00002) \\
\text { Combined risk of mortality or } \\
\text { HF hospitalization } \\
\text { HR } 0.69 \text { (95\% CI: } 0.59-0.81 \\
p=0.000004)\end{array}$ & $\begin{array}{c}\text { Carvedilol improved } \\
\text { all-cause LOHS HR } 0.73 \\
(p=0.0005) \text { and LOHS for } \\
\text { HF HR } 0.6(p<0.0001)\end{array}$ & \\
\hline
\end{tabular}


Table 1. Cont.

\begin{tabular}{|c|c|c|c|c|c|c|c|}
\hline Year & Reference & Patient Characteristics & Treatment & Mean Follow Up & Primary Endpoint & Secondary Endpoint & Comments \\
\hline \multicolumn{8}{|c|}{ ACE Inhibitors } \\
\hline 1987 & $\begin{array}{c}\text { CONSENSUS } \\
{[23]}\end{array}$ & $\begin{array}{l}253 \text { patients with severe } \\
\text { CHF NYHA functional } \\
\text { class IV }\end{array}$ & $\begin{array}{l}\text { Enalapril initial dose } \\
\text { of } 5 \mathrm{mg} \text { twice daily to } \\
\text { a maximal dose of } \\
20 \mathrm{mg} \text { twice daily vs. } \\
\text { placebo }\end{array}$ & 188 days & $\begin{array}{l}\text { Overall 6-month mortality } \\
\text { with enalapril vs. placebo HR } \\
0.6(p=0.002) \\
\text { 1-year mortality with enalapril } \\
\text { vs. placebo HR } 0.69(p=0.001) \\
\text { Mortality at the end of the } \\
\text { study with enalapril vs. } \\
\text { placebo HR } 0.73(p=0.003)\end{array}$ & $\begin{array}{l}\text { Enalapril improved } \\
\text { mortality, reduced heart } \\
\text { size, and reduced } \\
\text { requirement for other HF } \\
\text { medication }\end{array}$ & $\begin{array}{c}\text { Terminated early } \\
\text { because of a } \\
\text { significant mortality } \\
\text { benefit }\end{array}$ \\
\hline 1992 & SAVE [27] & $\begin{array}{l}2231 \text { patients with } \\
\text { LVEF } \leq 40 \% \text {, but without } \\
\text { overt HF or symptoms of } \\
\text { myocardial ischemia }\end{array}$ & $\begin{array}{c}\text { Captopril } 12.5 \mathrm{mg} \\
\text { up-titrated to } 50 \mathrm{mg} \\
\text { three times daily vs. } \\
\text { placebo }\end{array}$ & $\begin{array}{l}3 \text { years after } \\
\text { randomization }\end{array}$ & $\begin{array}{c}\text { All-cause mortality with } \\
\text { captopril vs. placebo HR } 0.79 \\
\text { (95\% CI: } 0.65-0.97, p=0.019) \\
\text { CV death HR 0.79 (95\% CI: } \\
0.65-0.95, p=0.014) \\
\text { MI HR 0.75 (95\% CI: } 0.6-0.95 \\
\quad p=0.012)\end{array}$ & $\begin{array}{c}\text { Captopril reduced risk for } \\
\text { the development of severe } \\
\text { HF HR } 0.63 \text { ( } 95 \% \text { CI: } \\
0.5-0.8, p<0.001) \text {, for CHF } \\
\text { requiring hospitalization } \\
\text { HR 0.78 (95\% CI: } 0.63-0.96 \text {, } \\
p=0.019) \text {, and for } \\
\text { recurrent MI HR } 0.75 \text { (95\% } \\
\text { CI: } 0.6-0.95, p=0.015)\end{array}$ & \\
\hline \multicolumn{8}{|c|}{ Angiotensin Receptor Blockers } \\
\hline 2001 & Val-HeFT [28] & $\begin{array}{l}5010 \text { patients with NYHA } \\
\text { class II, III, or IV }\end{array}$ & $\begin{array}{c}\text { Valsartan } 40 \mathrm{mg} \\
\text { twice daily } \\
\text { up-titrated to } 160 \mathrm{mg} \\
\text { of valsartan or } \\
\text { placebo twice daily }\end{array}$ & 23 months & $\begin{array}{c}\text { Mortality and morbidity } \\
\text { combined endpoint with } \\
\text { valsartan vs. placebo HR } 0.87 \\
\text { ( } 97.5 \% \text { CI: } 0.77-0.97) \\
\text { Risk with valsartan HR } 0.87 \\
\text { (97.5\% CI: } 0.77-0.97)\end{array}$ & $\begin{array}{c}\text { Valsartan reduced the risk } \\
\text { of HF hospitalization by } \\
27.5 \%(p<0.001) \\
\text { improved NYHA } \\
\text { classification in patients, } \\
\text { and relieved worsening } \\
\text { outcomes }(p<0.001)\end{array}$ & $\begin{array}{l}\text { Combined endpoints } \\
\text { benefit }-24 \% \\
\text { reduction in the rate } \\
\text { of adjudicated } \\
\text { hospitalizations for } \\
\text { worsening HF as a } \\
\text { first event in those } \\
\text { receiving valsartan }\end{array}$ \\
\hline
\end{tabular}


Table 1. Cont.

\begin{tabular}{|c|c|c|c|c|c|c|c|}
\hline Year & Reference & Patient Characteristics & Treatment & Mean Follow Up & Primary Endpoint & Secondary Endpoint & Comments \\
\hline 2003 & CHARM [30] & $\begin{array}{l}\text { 4576 CHF patients with } \\
\text { NYHA class II-IV with } \\
\text { LVEF } \leq 40 \%\end{array}$ & $\begin{array}{c}\text { Candesartan } 4 \mathrm{mg} \\
\text { once daily up-titrated } \\
\text { to a maximal dose of } \\
32 \mathrm{mg} \text { once daily vs. } \\
\text { placebo }\end{array}$ & $\begin{array}{l}\text { Median } \\
40 \text { months }\end{array}$ & $\begin{array}{c}\text { Risk of CV mortality or CHF } \\
\text { hospitalization with } \\
\text { candesartan vs. placebo HR } \\
0.82 \text { (95\% CI: } 0.74-0.90) \\
\text { Risk at } 1 \text { year, less } 30 \% \\
p<0.001 \\
\text { Risk at } 2 \text { years, less } 23 \% \\
p<0.001 \\
\text { All-cause mortality at } 1 \text { year, } \\
\text { less 33\% } p<0.001 \\
\text { All-cause mortality at } 2 \text { years, } \\
\text { less } 20 \% p=0.001\end{array}$ & $\begin{array}{c}\text { Candesartan improved } \\
\text { CHF hospitalization HR } \\
0.76 \text { (95\% CI: } 0.68-0.85, \\
p<0.001), \text { CV mortality } \\
\text { HR } 0.84 \text { (95\% CI: } 0.75-0.95 \\
\quad p=0.005)\end{array}$ & \\
\hline \multicolumn{8}{|c|}{ Mineralocorticoid Receptor Antagonists } \\
\hline 1999 & RALES [31] & $\begin{array}{l}1663 \text { CHF patients in } \\
\text { NYHA class III or IV, } \\
\text { treated with ACEi and } \\
\text { loop diuretic, and had } \\
\text { LVEF } \leq 35 \%\end{array}$ & $\begin{array}{l}\text { Spironolactone } 25 \mathrm{mg} \\
\text { once daily up-titrated } \\
\text { to } 50 \mathrm{mg} \text { once daily }\end{array}$ & 2 years & $\begin{array}{c}\text { Mortality with spironolactone } \\
\text { vs. placebo HR } 0.70 \text { ( } 95 \% \text { CI: } \\
0.60-0.82, p<0.001) \text { by a Cox } \\
\text { proportional-hazards model } \\
\text { Cardiac mortality HR } 0.69 \\
(95 \% \text { CI, } 0.58-0.82, p<0.001)\end{array}$ & $\begin{array}{c}\text { Spironolactone reduced } \\
\text { the risk of cardiac } \\
\text { hospitalization HR } 0.70 \\
(95 \% \text { CI: } 0.59-0.82 \\
p<0.001) \text {, and improved } \\
\text { the NYHA classification in } \\
\text { patients }\end{array}$ & $\begin{array}{l}\text { The trial was } \\
\text { discontinued early }\end{array}$ \\
\hline 2003 & EPHESUS [32] & $\begin{array}{c}6200 \text { patients, } 3 \text { to } 14 \text { days } \\
\text { after acute MI with } \\
\text { symptomatic HF and } \\
\text { LVEF } \leq 40 \%\end{array}$ & $\begin{array}{l}\text { Eplerenone } 25 \mathrm{mg} \\
\text { per day initially, } \\
\text { titrated to a } \\
\text { maximum of } 50 \mathrm{mg} \\
\text { per day vs. placebo }\end{array}$ & 16 months & $\begin{array}{c}\text { All-cause mortality } \\
\text { with eplerenone } \\
\text { vs. placebo HR } 0.85(p=0.008) \text {, } \\
\text { Risk of CV mortality or CV } \\
\text { hospitalization } \\
\text { HR } 0.87(p=0.002) \\
\text { Risk of all-cause mortality or } \\
\text { any hospitalization HR } 0.92 \\
(p=0.02)\end{array}$ & $\begin{array}{l}\text { Eplerenone reduced the } \\
\text { risk of SCD HR } 0.79 \\
(p=0.03), \text { reduced the risk } \\
\text { of HF hospitalization } 0.85 \\
(p=0.03) \text {, and reduced the } \\
\text { episodes of HF } \\
\text { hospitalization HR } 0.77 \\
(p=0.002)\end{array}$ & \\
\hline
\end{tabular}


Table 1. Cont.

\begin{tabular}{|c|c|c|c|c|c|c|c|}
\hline Year & Reference & Patient Characteristics & Treatment & Mean Follow Up & Primary Endpoint & Secondary Endpoint & Comments \\
\hline 2011 & $\begin{array}{c}\text { EMPHASIS-HF } \\
\text { [33] }\end{array}$ & $\begin{array}{l}2737 \text { patients }>55 \text { years, } \\
\text { with NYHA class II HF } \\
\text { and LVEF } \leq 35 \%\end{array}$ & $\begin{array}{l}\text { Eplerenone } 25 \mathrm{mg} \\
\text { per day initially, } \\
\text { titrated to a } \\
\text { maximum of } 50 \mathrm{mg} \\
\text { per day vs. placebo }\end{array}$ & $\begin{array}{l}\text { Median } \\
21 \text { months }\end{array}$ & $\begin{array}{c}\text { All-cause mortality or HF } \\
\text { hospitalization with } \\
\text { eplerenone vs. placebo HR } \\
0.63 \text { (95\% CI: } 0.54-0.74 \\
p<0.001)\end{array}$ & $\begin{array}{c}\text { Eplerenone reduced } \\
\text { all-cause mortality or HF } \\
\text { hospitalization HR } 0.65 \\
\text { (95\% CI: 0.55-0.76, } \\
p<0.001), \text { reduced } \\
\text { all-cause mortality HR } 0.76 \\
(95 \% \text { CI: } 0.62-0.93, \\
p=0.008), \text { reduced CV } \\
\text { mortality HR } 0.76(95 \% \text { CI, } \\
0.61-0.94, p=0.01), \text { and } \\
\text { reduced HF } \\
\text { hospitalization HR 0.58 } \\
(95 \% \text { CI: } 0.47-0.70, \\
p<0.001)\end{array}$ & $\begin{array}{c}\text { The trial was } \\
\text { discontinued early }\end{array}$ \\
\hline \multicolumn{8}{|c|}{ Nitrates and Hydralazine } \\
\hline 1986 & V-HeFT [34] & $\begin{array}{l}642 \text { chronic CHF patients } \\
\text { already taking furosemide } \\
\text { and digoxin }\end{array}$ & $\begin{array}{l}40 \mathrm{mg} \text { isosorbide } \\
\text { dinitrate and } 75 \mathrm{mg} \\
\text { hydralazine } \\
\text { administered four } \\
\text { times daily compared } \\
\text { to prazosin (5 mg } \\
\text { four times daily) and } \\
\text { to a placebo }\end{array}$ & 2.3 years & $\begin{array}{l}\text { For mortality by two years the } \\
\text { risk reduction among patients } \\
\text { treated with both hydralazine } \\
\text { and isosorbide dinitrate was } \\
\quad 34 \text { percent }(p<0.028)\end{array}$ & $\begin{array}{l}\text { The cumulative mortality } \\
\text { rates at two years were } \\
25.6 \text { percent in the } \\
\text { hydralazine-isosorbide } \\
\text { dinitrate group and } 34.3 \\
\text { percent in the placebo } \\
\text { group; at three years, the } \\
\text { mortality rate was } 36.2 \\
\text { percent versus } 46.9 \text { percent }\end{array}$ & \\
\hline 2004 & A-HeFT [35] & $\begin{array}{l}1050 \text { black patients who } \\
\text { had NYHA class III or IV } \\
\text { HF with dilated ventricles }\end{array}$ & $\begin{array}{c}37.5 \mathrm{mg} \text { of } \\
\text { hydralazine } \\
\text { hydrochloride and } \\
20 \mathrm{mg} \text { of isosorbide } \\
\text { dinitrate three times } \\
\text { daily to a total daily } \\
\text { dose of } 225 \mathrm{mg} \text { of } \\
\text { hydralazine } \\
\text { hydrochloride and } \\
120 \text { mg of isosorbide } \\
\text { dinitrate }\end{array}$ & 10 months & $\begin{array}{l}\text { All-cause mortality with } \\
\text { combined hydralazine } \\
\text { hydrochloride and isosorbide } \\
\text { dinitrate vs. placebo HR } 0.57 \\
(p=0.01) \text { by the log-rank test }\end{array}$ & $\begin{array}{l}\text { Combined hydralazine } \\
\text { hydrochloride and } \\
\text { isosorbide dinitrate } \\
\text { reduced first HF } \\
\text { hospitalizations by } 33 \% \\
(p=0.001) \text { and improved } \\
\text { the quality-of-life scores } \\
\text { (p=0.02) }\end{array}$ & $\begin{array}{c}\text { Terminated early } \\
\text { because of a } \\
\text { significant mortality } \\
\text { benefit }\end{array}$ \\
\hline
\end{tabular}


Table 1. Cont.

\begin{tabular}{|c|c|c|c|c|c|c|c|}
\hline Year & Reference & Patient Characteristics & Treatment & Mean Follow Up & Primary Endpoint & Secondary Endpoint & Comments \\
\hline 2014 & $\begin{array}{c}\text { PARADIGM-HF } \\
\text { [48] }\end{array}$ & $\begin{array}{l}8442 \text { patients with class II, } \\
\text { III, or IV HF and } \\
\text { LVEF } \leq 40 \%\end{array}$ & $\begin{array}{l}\text { Treatment with either } \\
\text { enalapril (at a dose of } \\
10 \mathrm{mg} \text { twice daily) or } \\
\text { LCZ696 (at a dose of } \\
200 \mathrm{mg} \text { twice daily) }\end{array}$ & $\begin{array}{l}\text { Median } \\
27 \text { months }\end{array}$ & $\begin{array}{c}\text { Risk of CV mortality or HF } \\
\text { hospitalization with LCZ696 } \\
\text { vs. placebo HR } 0.80(95 \% \text { CI: } \\
0.73-0.87, p<0.001)\end{array}$ & $\begin{array}{c}\text { LCZ696 reduced CV } \\
\text { mortality HR 0.80 (95\% CI: } \\
0.71-0.89, p<0.001), \\
\text { reduced HF } \\
\text { hospitalization HR } 0.79 \\
(95 \% \text { CI: } 0.71-0.89, \\
p<0.001) \text {, and reduced } \\
\text { all-cause mortality HR } 0.84 \\
(95 \% \text { CI: } 0.76-0.93, \\
p<0.001)\end{array}$ & $\begin{array}{c}\text { The trial was } \\
\text { discontinued early }\end{array}$ \\
\hline 2019 & $\begin{array}{c}\text { PIONEER-HF } \\
\text { [41] }\end{array}$ & $\begin{array}{l}881 \text { patients with } \\
\text { LVEF } \leq 40 \% \text {, elevated } \\
\text { NT-proBNP / BNP, and } \\
\text { received a primary } \\
\text { diagnosis of acute } \\
\text { decompensated HF, } \\
\text { including signs and } \\
\text { symptoms of fluid } \\
\text { overload }\end{array}$ & $\begin{array}{l}\text { The initial dose of } \\
\text { sacubitril-valsartan } \\
\text { (either } 24 \mathrm{mg} \text { of } \\
\text { sacubitril with } 26 \mathrm{mg} \\
\text { of valsartan or } 49 \mathrm{mg} \\
\text { of sacubitril with } \\
51 \mathrm{mg} \text { of valsartan as } \\
\text { a fixed-dose } \\
\text { combination) or } \\
\text { enalapril (either } \\
2.5 \text { mg or } 5 \mathrm{mg} \text { ) was } \\
\text { administered orally } \\
\text { twice daily }\end{array}$ & 8 weeks & $\begin{array}{l}\text { Time-averaged reduction in } \\
\text { NT-proBNP with } \\
\text { sacubitril-valsartan vs. } \\
\text { enalapril HR } 0.71(95 \% \text { CI: } \\
0.63-0.81, p<0.001)\end{array}$ & $\begin{array}{c}\text { NS worsening renal } \\
\text { function, hyperkalemia, } \\
\text { and symptomatic } \\
\text { hypotension between } \\
\text { sacubitril-valsartan vs. } \\
\text { enalapril; } \\
\text { sacubitril-valsartan } \\
\text { reduced the rate of } \\
\text { rehospitalization HR } 0.56 \\
\text { (CI: } 0.37-0.84 \text { ) and reduced } \\
\text { composite of serious } \\
\text { clinical events HR } 0.54(\mathrm{CI} \text { : } \\
0.37-0.79)\end{array}$ & \\
\hline \multicolumn{8}{|c|}{ Hyperpolarization-activated Cyclic Nucleotide (HCN) Channel Inhibitor } \\
\hline 2010 & SHIFT [36] & $\begin{array}{l}6558 \text { patients with } \\
\text { LVEF } \leq 35 \% \text {, sinus rhythm } \\
\text { with heart rate } \geq 70 \text { beats } \\
\text { per minute }\end{array}$ & $\begin{array}{l}\text { Ivabradine titrated to } \\
\text { a maximum of } 75 \mathrm{mg} \\
\text { twice daily or } \\
\text { matching placebo }\end{array}$ & $\begin{array}{c}\text { Median } \\
22.9 \text { months }\end{array}$ & $\begin{array}{c}\text { Risk of CV mortality or } \\
\text { worsening HF hospitalization } \\
\text { with ivabradine } \\
\text { vs. placebo HR } 0.82(95 \% \text { CI: } \\
0.75-0.90, p<0.0001) \\
\text { Risk of worsening HF } \\
\text { hospitalization } \\
\text { HR 0.74 (95\% CI: } 0.66-0.83 \\
p<0.0001) \\
\text { Risk of HF mortality HR } 0.74 \\
\text { (95\% CI: } 0.58-0.94, p=0.014)\end{array}$ & $\begin{array}{l}\text { Ivabradine reduced serious } \\
\text { adverse events }(p=0.025) \\
\text { increased symptomatic } \\
\text { bradycardia }(p<0.0001) \\
\text { and increased visual } \\
\text { side-effects }(p<0.0001)\end{array}$ & \\
\hline
\end{tabular}


Table 1. Cont.

\begin{tabular}{|c|c|c|c|c|c|c|c|}
\hline Year & Reference & Patient Characteristics & Treatment & Mean Follow Up & Primary Endpoint & Secondary Endpoint & Comments \\
\hline 2015 & EMPA-REG [60] & $\begin{array}{c}7020 \text { patients with type } 2 \\
\text { diabetes with established } \\
\text { CV disease }\end{array}$ & $\begin{array}{l}\text { Empagliflozin } 10 \mathrm{mg}, \\
\text { empagliflozin } 25 \mathrm{mg}, \\
\text { or placebo }(1: 1: 1)\end{array}$ & & $\begin{array}{c}\text { Primary outcome with } \\
\text { empagliflozin vs. placebo HR } \\
0.86 \text { ( } 95.02 \% \text { CI: } 0.74-0.99 \\
p<0.001 \text { for noninferiority } \\
p=0.04 \text { for superiority) }\end{array}$ & $\begin{array}{c}\text { Empagliflozin reduced the } \\
\text { key secondary outcome } \\
\text { HR } 0.89 \text { (95\% CI: } 0.78-1.01, \\
p<0.001 \text { for noninferiority, } \\
p=0.08 \text { for superiority) }\end{array}$ & \\
\hline 2019 & $\begin{array}{c}\text { DECLARE TIMI } \\
\text { [62] }\end{array}$ & $\begin{array}{c}\text { 17,160 patients, including } \\
10,186 \text { without } \\
\text { atherosclerotic CV disease } \\
\text { but with risk factors }\end{array}$ & $\begin{array}{l}\text { Dapagliflozin } 10 \mathrm{mg} \\
\text { or matching placebo }\end{array}$ & $\begin{array}{l}\text { Median } \\
4.2 \text { years }\end{array}$ & $\begin{array}{c}\text { Risk of mortality from CV } \\
\text { causes or HF hospitalization } \\
\text { with dapagliflozin vs. placebo } \\
\text { HR } 0.83 \text { (95\% CI: } 0.73-0.95 \text {, } \\
\quad p=0.005)\end{array}$ & $\begin{array}{l}\text { Dapagliflozin reduced the } \\
\text { incidence of renal } \\
\text { composite outcome }(>40 \% \\
\text { decrease in GFR to } \\
<60 \mathrm{~mL} / \mathrm{min} / 1.73 \mathrm{~m}^{2}, \\
\text { ESRD, or death from renal } \\
\text { or CV cause) HR } 0.76(95 \% \\
\text { CI: } 0.67-0.87)\end{array}$ & \\
\hline 2017 & CANVAS [63] & $\begin{array}{c}9734 \text { type } 2 \text { diabetes } \\
\text { patients and } \geq 30 \text { years, } \\
\text { with a history of } \\
\text { symptomatic } \\
\text { atherosclerotic } C V \text { disease, } \\
\text { or } \geq 50 \text { years with two or } \\
\text { more risk factors for CV } \\
\text { disease }\end{array}$ & $\begin{array}{l}\text { Canagliflozin } 300 \mathrm{mg}, \\
100 \mathrm{mg} \text { compared to } \\
\text { placebo }\end{array}$ & $\begin{array}{l}188.2 \text { weeks, } \\
\text { median } \\
126.1 \text { weeks }\end{array}$ & $\begin{array}{c}\text { Primary outcome with } \\
\text { canagliflozin vs. placebo HR } \\
0.86 \text { ( } 95 \% \text { CI: } 0.75-0.97 \\
p<0.001 \text { for noninferiority, } \\
p=0.02 \text { for superiority) }\end{array}$ & $\begin{array}{l}\text { Canagliflozin improved } \\
\text { the progression of } \\
\text { albuminuria HR } 0.73(95 \% \\
\text { CI: } 0.67-0.79) \text { and } \\
\text { improved the composite } \\
\text { outcome of a sustained } \\
40 \% \text { reduction in eGFR, } \\
\text { the need for renal } \\
\text { replacement therapy, or } \\
\text { death from renal causes } \\
\text { HR } 0.60 \text { ( } 95 \% \text { CI: } 0.47-0.77)\end{array}$ & \\
\hline 2019 & DAPA-HF [64] & $\begin{array}{c}4744 \text { patients with } \\
\text { LVEF } \leq 40 \% \text { and NYHA } \\
\text { functional class II, III, or IV } \\
\text { symptoms }\end{array}$ & $\begin{array}{l}\text { Dapagliflozin } 10 \mathrm{mg} \\
\text { once daily vs. } \\
\text { matching placebo }\end{array}$ & $\begin{array}{c}\text { Median } \\
18.2 \text { months }\end{array}$ & $\begin{array}{c}\text { Risk of mortality from CV } \\
\text { causes or HF } \\
\text { hospitalization/visit with } \\
\text { dapagliflozin vs. placebo HR } \\
0.74 \text { (95\% CI: } 0.65-0.85 \\
p<0.001)\end{array}$ & $\begin{array}{c}\text { Dapagliflozin reduced HF } \\
\text { hospitalizations or CV } \\
\text { mortality HR } 0.75(95 \% \mathrm{CI} \text { : } \\
0.65-0.85, p<0.001)\end{array}$ & \\
\hline
\end{tabular}


Table 1. Cont.

\begin{tabular}{|c|c|c|c|c|c|c|c|}
\hline Year & Reference & Patient Characteristics & Treatment & Mean Follow Up & Primary Endpoint & Secondary Endpoint & Comments \\
\hline 2020 & $\begin{array}{l}\text { EMPEROR- } \\
\text { reduced } \\
{[65]}\end{array}$ & $\begin{array}{c}3730 \text { patients with class II, } \\
\text { III, or IV HF and } \\
\text { LVEF } \leq 40 \%\end{array}$ & $\begin{array}{l}\text { Empagliflozin } 10 \mathrm{mg} \\
\text { once daily or placebo }\end{array}$ & $\begin{array}{l}\text { Median } \\
16 \text { months }\end{array}$ & $\begin{array}{c}\text { Risk of mortality from CV } \\
\text { causes or HF hospitalization } \\
\text { with empagliflozin vs. placebo } \\
\text { HR } 0.75 \text { ( } 95 \% \text { CI: } 0.65-0.86 \\
p<0.001) \\
\text { The effect of empagliflozin } \\
\text { was consistent in patients } \\
\text { regardless of the presence or } \\
\text { absence of diabetes }\end{array}$ & $\begin{array}{c}\text { Empagliflozin reduced HF } \\
\text { hospitalizations vs. } \\
\text { placebo HR } 0.70(95 \% \mathrm{CI} \text { : } \\
0.58-0.85, p<0.001) \\
\text { slowed the annual decline } \\
\text { rate in eGFR }(p<0.001), \\
\text { and reduced the risk of } \\
\text { serious renal outcomes }\end{array}$ & \\
\hline 2021 & $\begin{array}{l}\text { SOLOIST-WHF } \\
{[67]}\end{array}$ & $\begin{array}{l}1222 \text { type } 2 \text { diabetes } \\
\text { patients, recently } \\
\text { hospitalized due to } \\
\text { symptoms of HF, and } \\
\text { received treatment with } \\
\text { intravenous diuretic } \\
\text { therapy }\end{array}$ & $\begin{array}{l}200 \mathrm{mg} \text { of } \\
\text { sotagliflozin once } \\
\text { daily (with a dose } \\
\text { increase to } 400 \mathrm{mg} \text {, } \\
\text { depending on side } \\
\text { effects) or placebo }\end{array}$ & $\begin{array}{l}\text { Median } \\
9.2 \text { months }\end{array}$ & $\begin{array}{l}\text { Rate of primary endpoint } \\
\text { events with sotagliflozin vs. } \\
\text { placebo HR } 0.67 \text { (95\% CI: } \\
0.52-0.85, p<0.001) \text { for an } \\
\text { absolute difference of } 25.3 \\
\text { events per } 100 \text { patient-years } \\
\text { (95\% CI: } 5.1-45.6)\end{array}$ & $\begin{array}{l}\text { Sotagliflozin reduced CV } \\
\text { mortality rates HR } 0.84 \\
\text { (95\% CI: } 0.58-1.22) \text { and } \\
\text { reduced all-cause mortality } \\
\text { rates, HR } 0.82(95 \% \text { CI: } \\
0.59-1.14)\end{array}$ & \\
\hline 2020 & VERTIS-CV [68] & $\begin{array}{c}8246 \text { type } 2 \text { diabetes } \\
\text { patients with } \\
\text { atherosclerotic } C V \text { disease }\end{array}$ & $\begin{array}{l}5 \mathrm{mg} \text { or } 15 \mathrm{mg} \text { of } \\
\text { ertugliflozin or } \\
\text { placebo }\end{array}$ & 3.5 years & $\begin{array}{c}\text { Risk of mortality from CV } \\
\text { causes or HF hospitalization } \\
\text { with ertugliflozin vs. placebo } \\
\text { HR } 0.88 \text { ( } 95.8 \% \text { CI: } 0.75-1.03 \\
\quad p=0.11 \text { for superiority) }\end{array}$ & $\begin{array}{c}\text { Ertugliflozin reduced CV } \\
\text { mortality HR } 0.92(95.8 \% \\
\text { CI: } 0.77-1.11) \text { and reduced } \\
\text { mortality from renal } \\
\text { causes, renal replacement } \\
\text { therapy, or doubling of the } \\
\text { serum creatinine level HR } \\
0.81 \text { (95.8\% CI: } 0.63-1.04)\end{array}$ & $\begin{array}{c}\text { Major adverse CV } \\
\text { events occurred in } \\
653 \text { of } 5493 \\
\text { ertugliflozin patients } \\
(11.9 \%) \text { vs. } 327 \text { of } \\
2745 \text { placebo patients } \\
(11.9 \%)(\mathrm{HR}, 0.97 ; \\
95.6 \% \mathrm{CI}, 0.85-1.11 ; \\
p<0.001 \text { for } \\
\text { noninferiority) }\end{array}$ \\
\hline
\end{tabular}


Table 1. Cont.

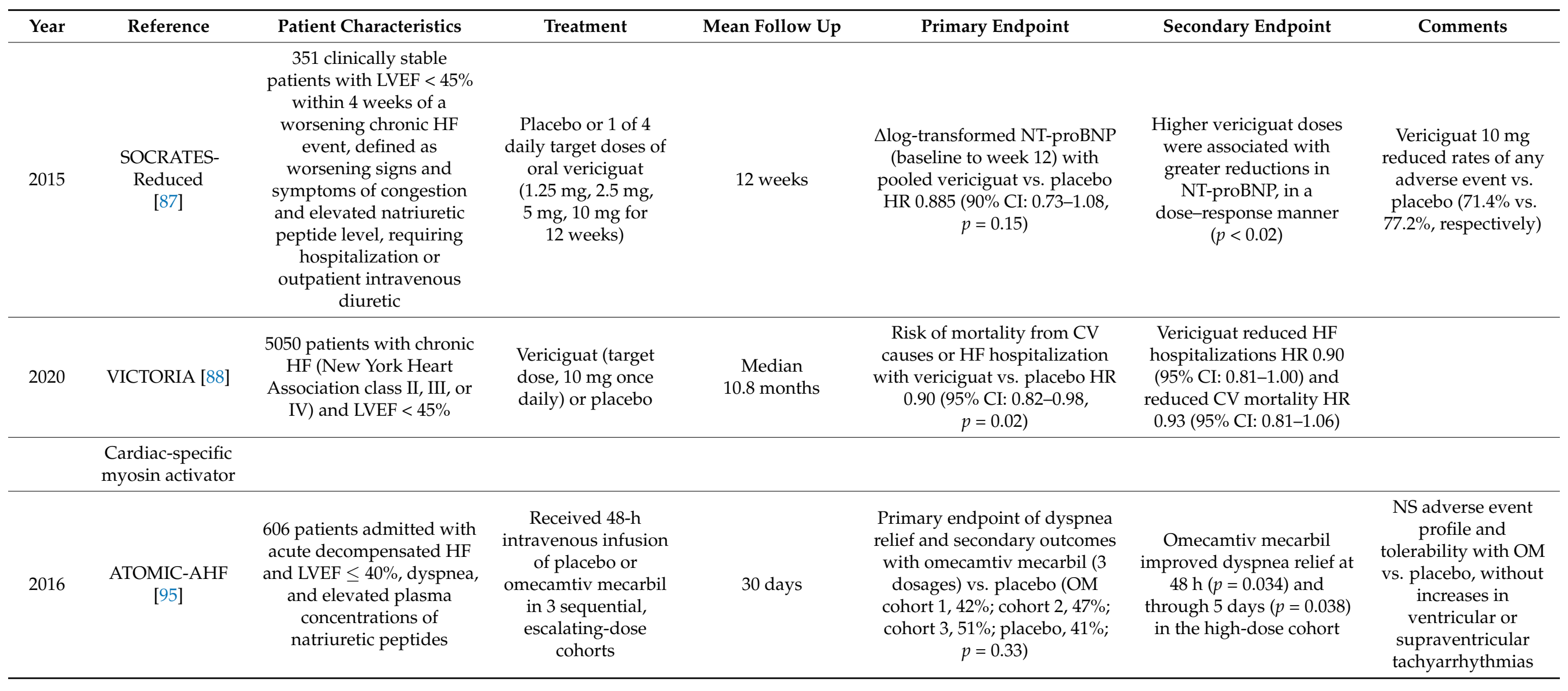


Table 1. Cont.

\begin{tabular}{|c|c|c|c|c|c|c|c|}
\hline Year & Reference & Patient Characteristics & Treatment & Mean Follow Up & Primary Endpoint & Secondary Endpoint & Comments \\
\hline 2016 & COSMIC-HF [96] & $\begin{array}{l}299 \text { patients with stable, } \\
\text { symptomatic chronic HF } \\
\text { and LVEF } \leq 40 \%\end{array}$ & $\begin{array}{c}\text { Received } 25 \text { mg oral } \\
\text { omecamtiv mecarbil } \\
\text { twice daily } \\
\text { (fixed-dose group), } \\
25 \mathrm{mg} \text { twice daily } \\
\text { titrated to } 50 \mathrm{mg} \\
\text { twice daily guided by } \\
\text { pharmacokinetics } \\
\text { (pharmacokinetic } \\
\text { titration group), or } \\
\text { placebo for } 20 \text { weeks }\end{array}$ & 24 weeks & $\begin{array}{c}\text { Mean maximum concentration } \\
\text { of omecamtiv mecarbil at } 12 \\
\text { weeks was } 200 \pm 71 \mathrm{ng} / \mathrm{mL} \text { in } \\
\text { the fixed-dose group and } \\
318 \pm 129 \mathrm{ng} / \mathrm{mL} \text { in the } \\
\text { pharmacokinetic titration } \\
\text { group }\end{array}$ & $\begin{array}{c}\text { Omecamtiv mecarbil } \\
\text { improved systolic ejection } \\
\text { time (95\% CI: } 18-32, \\
p<0.0001), \text { stroke volume } \\
\text { (CI: } 0.5-6.7, p=0.0217), \\
\text { LVESD (CI: }-2.9 \text { to }-0.6, \\
p=0.0027), \text { LVEDD (CI: } \\
-2.3 \text { to } 0.3, p=0.0128), \\
\text { heart rate (CI: }-5.1 \text { to }-0.8, \\
p=0.0070), \text { and } \\
\text { NT-proBNP concentration } \\
\text { in plasma }(p=0.0069)\end{array}$ & \\
\hline 2021 & $\begin{array}{c}\text { GALACTIC-HF } \\
{[97]}\end{array}$ & $\begin{array}{l}8256 \text { patients (inpatients } \\
\text { and outpatients) with } \\
\text { symptomatic chronic HF } \\
\text { and LVEF } \leq 35 \%\end{array}$ & $\begin{array}{l}\text { Omecamtiv mecarbil } \\
\text { (using } \\
\text { pharmacokinetic- } \\
\text { guided doses of } \\
25 \mathrm{mg}, 37.5 \mathrm{mg} \text {, or } \\
50 \mathrm{mg} \text { twice daily) or } \\
\text { placebo }\end{array}$ & $\begin{array}{c}\text { Median } \\
21.8 \text { months }\end{array}$ & $\begin{array}{c}\text { Risk of CV mortality or HF } \\
\text { hospitalization/visit with } \\
\text { omecamtiv mecarbil vs. } \\
\text { placebo HR } 0.92(95 \% \text { CI: } \\
0.86-0.99, p=0.03)\end{array}$ & $\begin{array}{l}\text { NS CV mortality with } \\
\text { omecamtiv mecarbil HR } \\
1.01 \text { (95\% CI: 0.92-1.11), } \\
\text { and NS in the change from } \\
\text { baseline on the Kansas } \\
\text { City Cardiomyopathy } \\
\text { Questionnaire total } \\
\text { symptom score }\end{array}$ & $\begin{array}{l}\text { NS frequency of } \\
\text { cardiac ischemic and } \\
\text { ventricular } \\
\text { arrhythmia events } \\
\text { with OM vs. placebo }\end{array}$ \\
\hline
\end{tabular}

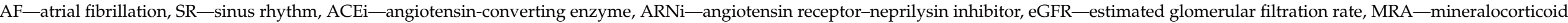
receptor antagonist, SGLT2i-sodium-glucose transport protein inhibitor. 


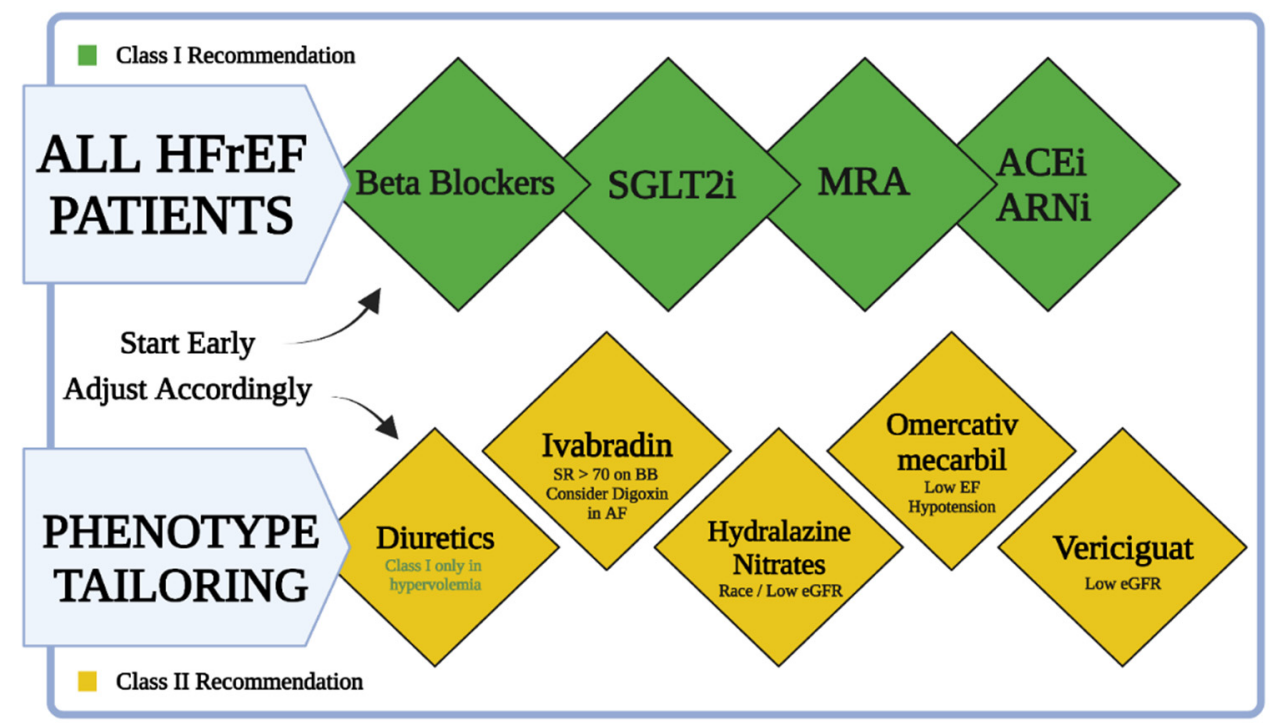

Figure 4. A simplified chart for treatment of HFrEF patients. All HFrEF patients should be started on beta-blockers, SGLT2i, MRAs, and ARNi (or ACEi) as soon as possible after diagnosis. Ivabradine should be considered in patients already on beta-blockers with sinus rhythm (SR) and heart rate $>70$. Hydralazine and isosorbide dinitrate should be considered in self-identified black patients with LVEF $<35 \%$ despite optimal treatment and may be considered in those who cannot tolerate $\mathrm{ACEi}, \mathrm{ARB}$, or ARNi treatment. Omecamtiv mecarbil is a treatment option for patients with hypotension and low eGFR. Vericiguat may be considered in patients with NYHA class II-IV who have worsening HF and low eGFR despite optimal treatment.

\section{Future Perspectives and Conclusions}

Based on a large series of clinical trials, it appears that SGLT2i have the largest effect, hence they have become a class I recommendation in the recent ESC guidelines for chronic HFrEF. Omecamtiv mecarbil and vericiguat have provided less striking results, probably directing their clinical use to specific clinical scenarios, such as omecamtiv mecarbil's use for patients with lower systolic blood pressure. The future holds tremendous and exciting pharmacologic avenues to be explored. The role of inflammation in morbidity and mortality outcomes in HF patients is a primary area of interest. Genetic analysis of HF patients might shed light on the variation in responses to specific medications, and personalized therapeutic regimens may be suited accordingly. Alongside the tremendous developments described in this manuscript, the rate of patients receiving guideline-directed medical therapy is still low [100]. Therefore, increasing efforts to improve adherence to optimal medical therapy for HFrEF patients is mandatory to achieve maximal clinical benefits.

Author Contributions: E.R., D.N., R.A. conceptualized the review. E.R., D.N., O.Y. wrote the first draft. M.Y., O.A., G.E.-G., R.A. provided critical editing and review. All authors have read and agreed to the published version of the manuscript.

Funding: This research received no external funding.

Institutional Review Board Statement: Not applicable.

Informed Consent Statement: Not applicable.

Data Availability Statement: Not applicable.

Acknowledgments: All figures were created using Biorender.com.

Conflicts of Interest: Offer Amir COI: Advisory board and lecture's honorarium for Boehringer Ingelheim, Bayer, AstraZeneca, Novartis, Pfizer. 


\section{References}

1. Libby, P.; Bonow, R.O.; Mann, D.L.; Tomaselli, G.F.; Bhattt, D.L.; Solomon, S. Braunwald's Heart Disease: A Textbook of Cardiovascular Medicine, 12th ed.; Elsevier: Philadelphia, PA, USA, 2021.

2. Metra, M.; Teerlink, J.R. Heart failure. Lancet 2017, 390, 1981-1995. [CrossRef]

3. Rossignol, P.; Hernandez, A.F.; Solomon, S.D.; Zannad, F. Heart failure drug treatment. Lancet 2019, 393, 1034-1044. [CrossRef]

4. Cook, C.; Cole, G.; Asaria, P.; Jabbour, R.; Francis, D.P. The annual global economic burden of heart failure. Int. J. Cardiol. 2014, 171, 368-376. [CrossRef]

5. Heidenreich, P.A.; Albert, N.M.; Allen, L.A.; Bluemke, D.A.; Butler, J.; Fonarow, G.C.; Ikonomidis, J.S.; Khavjou, O.; Konstam, M.A.; Maddox, T.M.; et al. Forecasting the impact of heart failure in the United States: A policy statement from the American Heart Association. Circ. Heart Fail. 2013, 6, 606-619. [CrossRef] [PubMed]

6. Savarese, G.; Lund, L.H. Global public health burden of heart failure. Card. Fail. Rev. 2017, 3, 7-11. [CrossRef]

7. Virani, S.S.; Alonso, A.; Aparicio, H.J.; Benjamin, E.J.; Bittencourt, M.S.; Callaway, C.W.; Carson, A.P.; Chamberlain, A.M.; Cheng, S.; Delling, F.N.; et al. Heart disease and stroke statistics-2021 update: A report from the American Heart Association. Circulation 2021, 143, e254-e743. [CrossRef] [PubMed]

8. Virani, S.S.; Alonso, A.; Benjamin, E.J.; Bittencourt, M.S.; Callaway, C.W.; Carson, A.P.; Chamberlain, A.M.; Chang, A.R.; Cheng, S.; Delling, F.N.; et al. Heart disease and stroke statistics-2020 update: A report from the American Heart Association. Circulation 2020, 141, e139-e596. [CrossRef]

9. Benjamin, E.J.; Muntner, P.; Alonso, A.; Bittencourt, M.S.; Callaway, C.W.; Carson, A.P.; Chamberlain, A.M.; Chang, A.R.; Cheng, S.; Das, S.R.; et al. Heart disease and stroke statistics-2019 update: A report from the American Heart Association. Circulation 2019, 139, e56-e528. [CrossRef] [PubMed]

10. Ziaeian, B.; Fonarow, G.C. Epidemiology and aetiology of heart failure. Nat. Rev. Cardiol. 2016, 13, 368-378. [CrossRef] [PubMed]

11. McMurray, J.J.; Stewart, S. Epidemiology, aetiology, and prognosis of heart failure. Heart 2000, 83, 596-602. [CrossRef]

12. Ponikowski, P.; Voors, A.A.; Anker, S.D.; Bueno, H.; Cleland, J.G.F.; Coats, A.J.S.; Falk, V.; Gonzalez-Juanatey, J.R.; Harjola, V.P.; Jankowska, E.A.; et al. 2016 ESC Guidelines for the diagnosis and treatment of acute and chronic heart failure: The Task Force for the diagnosis and treatment of acute and chronic heart failure of the European Society of Cardiology (ESC) Developed with the special contribution of the Heart Failure Association (HFA) of the ESC. Eur. Heart J. 2016, 37, 2129-2200. [CrossRef]

13. Ponikowski, P.; Voors, A.A.; Anker, S.D.; Bueno, H.; Cleland, J.G.; Coats, A.J.; Falk, V.; Gonzalez-Juanatey, J.R.; Harjola, V.P.; Jankowska, E.A.; et al. 2016 ESC Guidelines for the diagnosis and treatment of acute and chronic heart failure. Kardiol. Pol. 2016, 74, 1037-1147. [CrossRef]

14. McDonagh, T.A.; Metra, M.; Adamo, M.; Gardner, R.S.; Baumbach, A.; Bohm, M.; Burri, H.; Butler, J.; Celutkiene, J.; Chioncel, O.; et al. 2021 ESC Guidelines for the diagnosis and treatment of acute and chronic heart failure. Eur. Heart J. 2021. [CrossRef] [PubMed]

15. Cohn, J.N.; Ferrari, R.; Sharpe, N.; International Forum on Cardiac Remodeling. Cardiac remodeling-Concepts and clinical implications: A consensus paper from an international forum on cardiac remodeling. J. Am. Coll. Cardiol. 2000, 35, 569-582. [CrossRef]

16. Yancy, C.W.; Jessup, M.; Bozkurt, B.; Butler, J.; Casey, D.E., Jr.; Colvin, M.M.; Drazner, M.H.; Filippatos, G.S.; Fonarow, G.C.; Givertz, M.M.; et al. 2017 ACC/AHA/HFSA focused update of the 2013 ACCF/AHA guideline for the management of heart failure: A report of the American College of Cardiology/American Heart Association task force on clinical practice guidelines and the Heart Failure Society of America. Circulation 2017, 136, e137-e161. [CrossRef] [PubMed]

17. Waagstein, F.; Hjalmarson, A.; Varnauskas, E.; Wallentin, I. Effect of chronic beta-adrenergic receptor blockade in congestive cardiomyopathy. Br. Heart J. 1975, 37, 1022-1036. [CrossRef]

18. CIBIS Investigators and Committees. A randomized trial of beta-blockade in heart failure. The Cardiac Insufficiency Bisoprolol Study (CIBIS). Circulation 1994, 90, 1765-1773. [CrossRef]

19. CIBIS-II Investigators and Committees. The Cardiac Insufficiency Bisoprolol Study II (CIBIS-II): A randomised trial. Lancet 1999, 353, 9-13. [CrossRef]

20. MERIT-HF Study Group. Effect of metoprolol CR/XL in chronic heart failure: Metoprolol CR/XL Randomised Intervention Trial in Congestive Heart Failure (MERIT-HF). Lancet 1999, 353, 2001-2007. [CrossRef]

21. Packer, M.; Fowler, M.B.; Roecker, E.B.; Coats, A.J.; Katus, H.A.; Krum, H.; Mohacsi, P.; Rouleau, J.L.; Tendera, M.; Staiger, C.; et al. Effect of carvedilol on the morbidity of patients with severe chronic heart failure: Results of the carvedilol prospective randomized cumulative survival (COPERNICUS) study. Circulation 2002, 106, 2194-2199. [CrossRef]

22. Poole-Wilson, P.A.; Swedberg, K.; Cleland, J.G.; Di Lenarda, A.; Hanrath, P.; Komajda, M.; Lubsen, J.; Lutiger, B.; Metra, M.; Remme, W.J.; et al. Comparison of carvedilol and metoprolol on clinical outcomes in patients with chronic heart failure in the Carvedilol Or Metoprolol European Trial (COMET): Randomised controlled trial. Lancet 2003, 362, 7-13. [CrossRef]

23. Swedberg, K.; John, K.; CONSENSUS Trial Study Group. Effects of enalapril on mortality in severe congestive heart failure. Results of the Cooperative North Scandinavian Enalapril Survival Study (CONSENSUS). N. Engl. J. Med. 1987, 316, 1429-1435. [CrossRef]

24. SOLVD Investigators; Yusuf, S.; Pitt, B.; Davis, C.E.; Hood, W.B.; Cohn, J.N. Effect of enalapril on survival in patients with reduced left ventricular ejection fractions and congestive heart failure. N. Engl. J. Med. 1991, 325, 293-302. [CrossRef] [PubMed]

25. V-HeFT positive for enalapril. Br. J. Hosp. Med. 1991, 45, 233. 
26. Cohn, J.N. Lessons from V-HeFT: Questions for V-HeFT II and the future therapy of heart failure. Herz 1991, 16, $267-271$. [PubMed]

27. Pfeffer, M.A.; Braunwald, E.; Moye, L.A.; Basta, L.; Brown, E.J., Jr.; Cuddy, T.E.; Davis, B.R.; Geltman, E.M.; Goldman, S.; Flaker, G.C.; et al. Effect of captopril on mortality and morbidity in patients with left ventricular dysfunction after myocardial infarction. Results of the survival and ventricular enlargement trial. The SAVE Investigators. N. Engl. J. Med. 1992, 327, 669-677. [CrossRef]

28. Haghfelt, T. Val-HeFT-Valsartan Heart Failure Trial. Ugeskr Laeger 2001, 163, 1867.

29. Pfeffer, M.A.; Swedberg, K.; Granger, C.B.; Held, P.; McMurray, J.J.; Michelson, E.L.; Olofsson, B.; Östergren, J.; Yusuf, S. Effects of candesartan on mortality and morbidity in patients with chronic heart failure: The CHARM-Overall programme. Lancet 2003, 362, 759-766. [CrossRef]

30. Granger, C.B.; McMurray, J.J.; Yusuf, S.; Held, P.; Michelson, E.L.; Olofsson, B.; Ostergren, J.; Pfeffer, M.A.; Swedberg, K.; CHARM Investigators and Committees; et al. Effects of candesartan in patients with chronic heart failure and reduced left-ventricular systolic function intolerant to angiotensin-converting-enzyme inhibitors: The CHARM-Alternative trial. Lancet 2003, 362, 772-776. [CrossRef]

31. Schwinger, R.H. The aldosterone antagonist spironolactone prolongs the survival of chronic heart failure patients. The results of the RALES study. The Randomized Aldactone Evaluation Study. Dtsch. Med. Wochenschr. 1999, 124, 987-988. [PubMed]

32. Pitt, B.; Remme, W.; Zannad, F.; Neaton, J.; Martinez, F.; Roniker, B.; Bittman, R.; Hurley, S.; Kleiman, J.; Gatlin, M.; et al. Eplerenone, a selective aldosterone blocker, in patients with left ventricular dysfunction after myocardial infarction. N. Engl. J. Med. 2003, 348, 1309-1321. [CrossRef] [PubMed]

33. Zannad, F.; McMurray, J.J.; Krum, H.; van Veldhuisen, D.J.; Swedberg, K.; Shi, H.; Vincent, J.; Pocock, S.J.; Pitt, B.; Group, E.-H.S. Eplerenone in patients with systolic heart failure and mild symptoms. N. Engl. J. Med. 2011, 364, 11-21. [CrossRef] [PubMed]

34. Cohn, J.N.; Archibald, D.G.; Ziesche, S.; Franciosa, J.A.; Harston, W.E.; Tristani, F.E.; Dunkman, W.B.; Jacobs, W.; Francis, G.S.; Flohr, K.H.; et al. Effect of vasodilator therapy on mortality in chronic congestive heart failure. Results of a Veterans Administration Cooperative Study. N. Engl. J. Med. 1986, 314, 1547-1552. [CrossRef]

35. Taylor, A.L.; Ziesche, S.; Yancy, C.; Carson, P.; D’Agostino, R., Jr.; Ferdinand, K.; Taylor, M.; Adams, K.; Sabolinski, M.; Worcel, M.; et al. Combination of isosorbide dinitrate and hydralazine in blacks with heart failure. N. Engl. J. Med. 2004, 351, 2049-2057. [CrossRef]

36. Swedberg, K.; Komajda, M.; Bohm, M.; Borer, J.S.; Ford, I.; Dubost-Brama, A.; Lerebours, G.; Tavazzi, L.; SHIFT Investigators. Ivabradine and outcomes in chronic heart failure (SHIFT): A randomised placebo-controlled study. Lancet 2010, 376, 875-885. [CrossRef]

37. Ponikowski, P.; Voors, A.A.; Anker, S.D.; Bueno, H.; Cleland, J.G.; Coats, A.J.; Falk, V.; Gonzalez-Juanatey, J.R.; Harjola, V.P.; Jankowska, E.A.; et al. 2016 ESC Guidelines for the diagnosis and treatment of acute and chronic heart failure: The Task Force for the diagnosis and treatment of acute and chronic heart failure of the European Society of Cardiology (ESC). Developed with the special contribution of the Heart Failure Association (HFA) of the ESC. Eur. J. Heart Fail. 2016, 18, 891-975. [CrossRef]

38. Digitalis Investigation Group. The effect of digoxin on mortality and morbidity in patients with heart failure. N. Engl. J. Med. 1997, 336, 525-533. [CrossRef] [PubMed]

39. Shah, K.S.; Xu, H.; Matsouaka, R.A.; Bhatt, D.L.; Heidenreich, P.A.; Hernandez, A.F.; Devore, A.D.; Yancy, C.W.; Fonarow, G.C. Heart failure with preserved, borderline, and reduced ejection fraction: 5-year outcomes. J. Am. Coll. Cardiol. 2017, 70, 2476-2486. [CrossRef]

40. Hunt, S.A.; Abraham, W.T.; Chin, M.H.; Feldman, A.M.; Francis, G.S.; Ganiats, T.G.; Jessup, M.; Konstam, M.A.; Mancini, D.M.; Michl, K.; et al. 2009 focused update incorporated into the ACC/AHA 2005 Guidelines for the Diagnosis and Management of Heart Failure in Adults: A report of the American College of Cardiology Foundation/American Heart Association Task Force on Practice Guidelines: Developed in collaboration with the International Society for Heart and Lung Transplantation. Circulation 2009, 119, e391-e479. [CrossRef]

41. Velazquez, E.J.; Morrow, D.A.; DeVore, A.D.; Duffy, C.I.; Ambrosy, A.P.; McCague, K.; Rocha, R.; Braunwald, E.; PIONEER-HF Investigators. Angiotensin-neprilysin inhibition in acute decompensated heart failure. N. Engl. J. Med. 2019, 380, 539-548. [CrossRef] [PubMed]

42. Kahn, J.C.; Patey, M.; Dubois-Rande, J.L.; Merlet, P.; Castaigne, A.; Lim-Alexandre, C.; Lecomte, J.M.; Duboc, D.; Gros, C.; Schwartz, J.C. Effect of sinorphan on plasma atrial natriuretic factor in congestive heart failure. Lancet 1990, 335, 118-119. [CrossRef]

43. Northridge, D.B.; Jardine, A.G.; Alabaster, C.T.; Barclay, P.L.; Connell, J.M.; Dargie, H.J.; Dilly, S.G.; Findlay, I.N.; Lever, A.F.; Samuels, G.M. Effects of UK 69 578: A novel atriopeptidase inhibitor. Lancet 1989, 2, 591-593. [CrossRef]

44. Packer, M.; Califf, R.M.; Konstam, M.A.; Krum, H.; McMurray, J.J.; Rouleau, J.L.; Swedberg, K. Comparison of omapatrilat and enalapril in patients with chronic heart failure: The Omapatrilat Versus Enalapril Randomized Trial of Utility in Reducing Events (OVERTURE). Circulation 2002, 106, 920-926. [CrossRef]

45. Ruilope, L.M.; Dukat, A.; Bohm, M.; Lacourciere, Y.; Gong, J.; Lefkowitz, M.P. Blood-pressure reduction with LCZ696, a novel dual-acting inhibitor of the angiotensin II receptor and neprilysin: A randomised, double-blind, placebo-controlled, active comparator study. Lancet 2010, 375, 1255-1266. [CrossRef] 
46. Gu, J.; Noe, A.; Chandra, P.; Al-Fayoumi, S.; Ligueros-Saylan, M.; Sarangapani, R.; Maahs, S.; Ksander, G.; Rigel, D.F.; Jeng, A.Y.; et al. Pharmacokinetics and pharmacodynamics of LCZ696, a novel dual-acting angiotensin receptor-neprilysin inhibitor (ARNi). J. Clin. Pharmacol. 2010, 50, 401-414. [CrossRef]

47. Hegde, L.G.; Yu, C.; Renner, T.; Thibodeaux, H.; Armstrong, S.R.; Park, T.; Cheruvu, M.; Olsufka, R.; Sandvik, E.R.; Lane, C.E.; et al. Concomitant angiotensin AT1 receptor antagonism and neprilysin inhibition produces omapatrilat-like antihypertensive effects without promoting tracheal plasma extravasation in the rat. J. Cardiovasc. Pharmacol. 2011, 57, 495-504. [CrossRef]

48. McMurray, J.J.; Packer, M.; Desai, A.S.; Gong, J.; Lefkowitz, M.P.; Rizkala, A.R.; Rouleau, J.L.; Shi, V.C.; Solomon, S.D.; Swedberg, K.; et al. Angiotensin-neprilysin inhibition versus enalapril in heart failure. N. Engl. J. Med. 2014, 371, 993-1004. [CrossRef] [PubMed]

49. Velazquez, E.J.; Morrow, D.A.; DeVore, A.D.; Ambrosy, A.P.; Duffy, C.I.; McCague, K.; Hernandez, A.F.; Rocha, R.A.; Braunwald, E. Rationale and design of the comParIson Of sacubitril/valsartaN versus Enalapril on Effect on nt-pRo-bnp in patients stabilized from an acute Heart Failure episode (PIONEER-HF) trial. Am. Heart J. 2018, 198, 145-151. [CrossRef] [PubMed]

50. Berg, D.D.; Samsky, M.D.; Velazquez, E.J.; Duffy, C.I.; Gurmu, Y.; Braunwald, E.; Morrow, D.A.; DeVore, A.D. Efficacy and safety of sacubitril/valsartan in high-risk patients in the PIONEER-HF trial. Circ. Heart Fail. 2021, 14, e007034. [CrossRef] [PubMed]

51. Vallon, V. The mechanisms and therapeutic potential of SGLT2 inhibitors in diabetes mellitus. Annu. Rev. Med. 2015, 66, 255-270. [CrossRef]

52. Plosker, G.L. Dapagliflozin: A review of its use in patients with type 2 diabetes. Drugs 2014, 74, 2191-2209. [CrossRef]

53. Thomas, M.C.; Cherney, D.Z.I. The actions of SGLT2 inhibitors on metabolism, renal function and blood pressure. Diabetologia 2018, 61, 2098-2107. [CrossRef] [PubMed]

54. Facchini, F.; Chen, Y.D.; Hollenbeck, C.B.; Reaven, G.M. Relationship between resistance to insulin-mediated glucose uptake, urinary uric acid clearance, and plasma uric acid concentration. JAMA 1991, 266, 3008-3011. [CrossRef] [PubMed]

55. Wanner, C.; Inzucchi, S.E.; Zinman, B. Empagliflozin and progression of kidney disease in type 2 diabetes. N. Engl. J. Med. 2016, 375, 1801-1802. [CrossRef] [PubMed]

56. Gaede, P.; Lund-Andersen, H.; Parving, H.H.; Pedersen, O. Effect of a multifactorial intervention on mortality in type 2 diabetes. N. Engl. J. Med. 2008, 358, 580-591. [CrossRef] [PubMed]

57. Li, H.; Shin, S.E.; Seo, M.S.; An, J.R.; Choi, I.W.; Jung, W.K.; Firth, A.L.; Lee, D.S.; Yim, M.J.; Choi, G.; et al. The anti-diabetic drug dapagliflozin induces vasodilation via activation of PKG and Kv channels. Life Sci. 2018, 197, 46-55. [CrossRef] [PubMed]

58. Al-Jobori, H.; Daniele, G.; Cersosimo, E.; Triplitt, C.; Mehta, R.; Norton, L.; DeFronzo, R.A.; Abdul-Ghani, M. Empagliflozin and kinetics of renal glucose transport in healthy individuals and individuals with type 2 diabetes. Diabetes 2017, 66, 1999-2006. [CrossRef]

59. Vasilakou, D.; Karagiannis, T.; Athanasiadou, E.; Mainou, M.; Liakos, A.; Bekiari, E.; Sarigianni, M.; Matthews, D.R.; Tsapas, A. Sodium-glucose cotransporter 2 inhibitors for type 2 diabetes: A systematic review and meta-analysis. Ann. Intern. Med. 2013, 159, 262-274. [CrossRef]

60. Zinman, B.; Wanner, C.; Lachin, J.M.; Fitchett, D.; Bluhmki, E.; Hantel, S.; Mattheus, M.; Devins, T.; Johansen, O.E.; Woerle, H.J.; et al. Empagliflozin, cardiovascular outcomes, and mortality in type 2 diabetes. N. Engl. J. Med. 2015, 373, 2117-2128. [CrossRef]

61. Mosenzon, O.; Wiviott, S.D.; Cahn, A.; Rozenberg, A.; Yanuv, I.; Goodrich, E.L.; Murphy, S.A.; Heerspink, H.J.L.; Zelniker, T.A.; Dwyer, J.P.; et al. Effects of dapagliflozin on development and progression of kidney disease in patients with type 2 diabetes: An analysis from the DECLARE-TIMI 58 randomised trial. Lancet Diabetes Endocrinol. 2019, 7, 606-617. [CrossRef]

62. Wiviott, S.D.; Raz, I.; Bonaca, M.P.; Mosenzon, O.; Kato, E.T.; Cahn, A.; Silverman, M.G.; Zelniker, T.A.; Kuder, J.F.; Murphy, S.A.; et al. Dapagliflozin and cardiovascular outcomes in type 2 diabetes. N. Engl. J. Med. 2019, 380, 347-357. [CrossRef] [PubMed]

63. Neal, B.; Perkovic, V.; Matthews, D.R. Canagliflozin and cardiovascular and renal events in type 2 diabetes. N. Engl. J. Med. 2017, 377, 2099. [CrossRef] [PubMed]

64. McMurray, J.J.V.; Solomon, S.D.; Inzucchi, S.E.; Kober, L.; Kosiborod, M.N.; Martinez, F.A.; Ponikowski, P.; Sabatine, M.S.; Anand, I.S.; Belohlavek, J.; et al. Dapagliflozin in patients with heart failure and reduced ejection fraction. N. Engl. J. Med. 2019, 381, 1995-2008. [CrossRef] [PubMed]

65. Packer, M.; Anker, S.D.; Butler, J.; Filippatos, G.; Pocock, S.J.; Carson, P.; Januzzi, J.; Verma, S.; Tsutsui, H.; Brueckmann, M.; et al. Cardiovascular and renal outcomes with empagliflozin in heart failure. N. Engl. J. Med. 2020, 383, 1413-1424. [CrossRef] [PubMed]

66. Zannad, F.; Ferreira, J.P.; Pocock, S.J.; Anker, S.D.; Butler, J.; Filippatos, G.; Brueckmann, M.; Ofstad, A.P.; Pfarr, E.; Jamal, W.; et al. SGLT2 inhibitors in patients with heart failure with reduced ejection fraction: A meta-analysis of the EMPEROR-Reduced and DAPA-HF trials. Lancet 2020, 396, 819-829. [CrossRef]

67. Bhatt, D.L.; Szarek, M.; Steg, P.G.; Cannon, C.P.; Leiter, L.A.; McGuire, D.K.; Lewis, J.B.; Riddle, M.C.; Voors, A.A.; Metra, M.; et al. Sotagliflozin in patients with diabetes and recent worsening heart failure. N. Engl. J. Med. 2021, 384, 117-128. [CrossRef] [PubMed] 
68. Cannon, C.P.; Pratley, R.; Dagogo-Jack, S.; Mancuso, J.; Huyck, S.; Masiukiewicz, U.; Charbonnel, B.; Frederich, R.; Gallo, S.; Cosentino, F.; et al. Cardiovascular outcomes with ertugliflozin in type 2 diabetes. N. Engl. J. Med. 2020, 383, $1425-1435$. [CrossRef] [PubMed]

69. Anker, S.D.; Butler, J.; Filippatos, G.; Ferreira, J.P.; Bocchi, E.; Bohm, M.; Brunner-La Rocca, H.P.; Choi, D.J.; Chopra, V.; Chuquiure-Valenzuela, E.; et al. Empagliflozin in heart failure with a preserved ejection fraction. N. Engl. J. Med. 2021. [CrossRef]

70. Farah, C.; Michel, L.Y.M.; Balligand, J.L. Nitric oxide signalling in cardiovascular health and disease. Nat. Rev. Cardiol. 2018, 15, 292-316. [CrossRef] [PubMed]

71. Tsai, E.J.; Kass, D.A. Cyclic GMP signaling in cardiovascular pathophysiology and therapeutics. Pharmacol. Ther. 2009, 122, 216-238. [CrossRef]

72. Maron, B.A.; Tang, S.S.; Loscalzo, J. S-nitrosothiols and the S-nitrosoproteome of the cardiovascular system. Antioxid. Redox Signal. 2013, 18, 270-287. [CrossRef] [PubMed]

73. Surks, H.K.; Mochizuki, N.; Kasai, Y.; Georgescu, S.P.; Tang, K.M.; Ito, M.; Lincoln, T.M.; Mendelsohn, M.E. Regulation of myosin phosphatase by a specific interaction with cGMP- dependent protein kinase Ialpha. Science 1999, 286, 1583-1587. [CrossRef] [PubMed]

74. Bolger, G.B. The PDE-opathies: Diverse phenotypes produced by a functionally related multigene family. Trends Genet. 2021, 37, 669-681. [CrossRef]

75. Paulus, W.J.; Tschope, C. A novel paradigm for heart failure with preserved ejection fraction: Comorbidities drive myocardial dysfunction and remodeling through coronary microvascular endothelial inflammation. J. Am. Coll. Cardiol. 2013, 62, $263-271$. [CrossRef]

76. Ferguson, S.K.; Woessner, M.N.; Holmes, M.J.; Belbis, M.D.; Carlstrom, M.; Weitzberg, E.; Allen, J.D.; Hirai, D.M. Effects of inorganic nitrate supplementation on cardiovascular function and exercise tolerance in heart failure. J. Appl. Physiol. 2021, 130, 914-922. [CrossRef]

77. Greene, S.J.; Gheorghiade, M.; Borlaug, B.A.; Pieske, B.; Vaduganathan, M.; Burnett, J.C., Jr.; Roessig, L.; Stasch, J.P.; Solomon, S.D.; Paulus, W.J.; et al. The cGMP signaling pathway as a therapeutic target in heart failure with preserved ejection fraction. $J$. Am. Heart Assoc. 2013, 2, e000536. [CrossRef]

78. Redfield, M.M.; Anstrom, K.J.; Levine, J.A.; Koepp, G.A.; Borlaug, B.A.; Chen, H.H.; LeWinter, M.M.; Joseph, S.M.; Shah, S.J.; Semigran, M.J.; et al. Isosorbide mononitrate in heart failure with preserved ejection fraction. N. Engl. J. Med. 2015, 373, 2314-2324. [CrossRef]

79. Leier, C.V.; Huss, P.; Magorien, R.D.; Unverferth, D.V. Improved exercise capacity and differing arterial and venous tolerance during chronic isosorbide dinitrate therapy for congestive heart failure. Circulation 1983, 67, 817-822. [CrossRef]

80. Franciosa, J.A.; Goldsmith, S.R.; Cohn, J.N. Contrasting immediate and long-term effects of isosorbide dinitrate on exercise capacity in congestive heart failure. Am. J. Med. 1980, 69, 559-566. [CrossRef]

81. Redfield, M.M.; Chen, H.H.; Borlaug, B.A.; Semigran, M.J.; Lee, K.L.; Lewis, G.; LeWinter, M.M.; Rouleau, J.L.; Bull, D.A.; Mann, D.L.; et al. Effect of phosphodiesterase-5 inhibition on exercise capacity and clinical status in heart failure with preserved ejection fraction: A randomized clinical trial. JAMA 2013, 309, 1268-1277. [CrossRef]

82. Hulot, J.S.; Trochu, J.N.; Donal, E.; Galinier, M.; Logeart, D.; De Groote, P.; Juilliere, Y. Vericiguat for the treatment of heart failure: Mechanism of action and pharmacological properties compared with other emerging therapeutic options. Expert Opin. Pharmacother. 2021, 1-9. [CrossRef] [PubMed]

83. Stasch, J.P.; Schmidt, P.; Alonso-Alija, C.; Apeler, H.; Dembowsky, K.; Haerter, M.; Heil, M.; Minuth, T.; Perzborn, E.; Pleiss, U.; et al. NO- and haem-independent activation of soluble guanylyl cyclase: Molecular basis and cardiovascular implications of a new pharmacological principle. Br. J. Pharmacol. 2002, 136, 773-783. [CrossRef]

84. Evgenov, O.V.; Pacher, P.; Schmidt, P.M.; Hasko, G.; Schmidt, H.H.; Stasch, J.P. NO-independent stimulators and activators of soluble guanylate cyclase: Discovery and therapeutic potential. Nat. Rev. Drug Discov. 2006, 5, 755-768. [CrossRef]

85. Gheorghiade, M.; Greene, S.J.; Filippatos, G.; Erdmann, E.; Ferrari, R.; Levy, P.D.; Maggioni, A.; Nowack, C.; Mebazaa, A.; Investigators, C.; et al. Cinaciguat, a soluble guanylate cyclase activator: Results from the randomized, controlled, phase IIb COMPOSE programme in acute heart failure syndromes. Eur. J. Heart Fail. 2012, 14, 1056-1066. [CrossRef]

86. Erdmann, E.; Semigran, M.J.; Nieminen, M.S.; Gheorghiade, M.; Agrawal, R.; Mitrovic, V.; Mebazaa, A. Cinaciguat, a soluble guanylate cyclase activator, unloads the heart but also causes hypotension in acute decompensated heart failure. Eur. Heart $J$. 2013, 34, 57-67. [CrossRef]

87. Gheorghiade, M.; Greene, S.J.; Butler, J.; Filippatos, G.; Lam, C.S.; Maggioni, A.P.; Ponikowski, P.; Shah, S.J.; Solomon, S.D.; Kraigher-Krainer, E.; et al. Effect of vericiguat, a soluble guanylate cyclase stimulator, on natriuretic peptide levels in patients with worsening chronic heart failure and reduced ejection fraction: The SOCRATES-REDUCED randomized trial. JAMA 2015, 314, 2251-2262. [CrossRef]

88. Armstrong, P.W.; Pieske, B.; Anstrom, K.J.; Ezekowitz, J.; Hernandez, A.F.; Butler, J.; Lam, C.S.P.; Ponikowski, P.; Voors, A.A.; Jia, G.; et al. Vericiguat in patients with heart failure and reduced ejection fraction. N. Engl. J. Med. 2020, 382, $1883-1893$. [CrossRef] [PubMed]

89. Teerlink, J.R. A novel approach to improve cardiac performance: Cardiac myosin activators. Heart Fail. Rev. 2009, 14, 289-298. [CrossRef] 
90. Shen, Y.T.; Malik, F.I.; Zhao, X.; Depre, C.; Dhar, S.K.; Abarzua, P.; Morgans, D.J.; Vatner, S.F. Improvement of cardiac function by a cardiac Myosin activator in conscious dogs with systolic heart failure. Circ. Heart Fail. 2010, 3, 522-527. [CrossRef] [PubMed]

91. Malik, F.I.; Hartman, J.J.; Elias, K.A.; Morgan, B.P.; Rodriguez, H.; Brejc, K.; Anderson, R.L.; Sueoka, S.H.; Lee, K.H.; Finer, J.T.; et al. Cardiac myosin activation: A potential therapeutic approach for systolic heart failure. Science 2011, 331, 1439-1443. [CrossRef]

92. Teerlink, J.R.; Clarke, C.P.; Saikali, K.G.; Lee, J.H.; Chen, M.M.; Escandon, R.D.; Elliott, L.; Bee, R.; Habibzadeh, M.R.; Goldman, J.H.; et al. Dose-dependent augmentation of cardiac systolic function with the selective cardiac myosin activator, omecamtiv mecarbil: A first-in-man study. Lancet 2011, 378, 667-675. [CrossRef]

93. Cleland, J.G.; Teerlink, J.R.; Senior, R.; Nifontov, E.M.; Mc Murray, J.J.; Lang, C.C.; Tsyrlin, V.A.; Greenberg, B.H.; Mayet, J.; Francis, D.P.; et al. The effects of the cardiac myosin activator, omecamtiv mecarbil, on cardiac function in systolic heart failure: A double-blind, placebo-controlled, crossover, dose-ranging phase 2 trial. Lancet 2011, 378, 676-683. [CrossRef]

94. Greenberg, B.H.; Chou, W.; Saikali, K.G.; Escandon, R.; Lee, J.H.; Chen, M.M.; Treshkur, T.; Megreladze, I.; Wasserman, S.M.; Eisenberg, P.; et al. Safety and tolerability of omecamtiv mecarbil during exercise in patients with ischemic cardiomyopathy and angina. JACC Heart Fail. 2015, 3, 22-29. [CrossRef] [PubMed]

95. Teerlink, J.R.; Felker, G.M.; McMurray, J.J.V.; Ponikowski, P.; Metra, M.; Filippatos, G.S.; Ezekowitz, J.A.; Dickstein, K.; Cleland, J.G.F.; Kim, J.B.; et al. Acute treatment with omecamtiv mecarbil to increase contractility in acute heart failure: The ATOMIC-AHF study. J. Am. Coll. Cardiol. 2016, 67, 1444-1455. [CrossRef] [PubMed]

96. Teerlink, J.R.; Felker, G.M.; McMurray, J.J.; Solomon, S.D.; Adams, K.F., Jr.; Cleland, J.G.; Ezekowitz, J.A.; Goudev, A.; Macdonald, P.; Metra, M.; et al. Chronic Oral Study of Myosin Activation to Increase Contractility in Heart Failure (COSMIC-HF): A phase 2, pharmacokinetic, randomised, placebo-controlled trial. Lancet 2016, 388, 2895-2903. [CrossRef]

97. Teerlink, J.R.; Diaz, R.; Felker, G.M.; McMurray, J.J.V.; Metra, M.; Solomon, S.D.; Adams, K.F.; Anand, I.; Arias-Mendoza, A.; Biering-Sorensen, T.; et al. Cardiac myosin activation with omecamtiv mecarbil in systolic heart failure. N. Engl. J. Med. 2021, 384, 105-116. [CrossRef] [PubMed]

98. Teerlink, J.R.; Diaz, R.; Felker, G.M.; McMurray, J.J.V.; Metra, M.; Solomon, S.D.; Biering-Sorensen, T.; Bohm, M.; Bonderman, D.; Fang, J.C.; et al. Effect of ejection fraction on clinical outcomes in patients treated with omecamtiv mecarbil in GALACTIC-HF. J. Am. Coll. Cardiol. 2021, 78, 97-108. [CrossRef] [PubMed]

99. Ponikowski, P.; Voors, A.A.; Anker, S.D.; Bueno, H.; Cleland, J.G.F.; Coats, A.J.S.; Falk, V.; Gonzalez-Juanatey, J.R.; Harjola, V.P.; Jankowska, E.A.; et al. 2016 ESC guidelines for the diagnosis and treatment of acute and chronic heart failure. Rev. Esp. Cardiol. (Engl. Ed.) 2016, 69, 1167. [CrossRef]

100. Komajda, M.; Anker, S.D.; Cowie, M.R.; Filippatos, G.S.; Mengelle, B.; Ponikowski, P.; Tavazzi, L.; QUALIFY Investigators. Physicians' adherence to guideline-recommended medications in heart failure with reduced ejection fraction: Data from the QUALIFY global survey. Eur. J. Heart Fail. 2016, 18, 514-522. [CrossRef] [PubMed] 